\author{
UNIVERSIDADE DE SÃO PAULO \\ ESCOLA DE ENFERMAGEM DE RIBEIRÃO PRETO \\ DEPARTAMENTO DE ENFERMAGEM GERAL E ESPECIALIZADA
}

BARBARA APARECIDA SEBASTIÃO

EFEITOS ADVERSOS NA SAÚDE DE CIRURGIÕES - DENTISTAS

E SUAS CORRELAÇÕES COM O USO DE EQUIPAMENTOS

MOTORES

RIBEIRÃO PRETO 
BARBARA APARECIDA SEBASTIÃO

\section{EFEITOS ADVERSOS NA SAÚDE DE CIRURGIÕES - DENTISTAS E SUAS CORRELAÇÕES COM O USO DE EQUIPAMENTOS MOTORES}

Dissertação apresentada ao Programa de Pós-Graduação em Enfermagem Fundamental da Escola de Enfermagem de Ribeirão Preto da Universidade de São Paulo para obtenção do título de Mestre em Enfermagem Fundamental.

Linha de Pesquisa: Saúde do Trabalhador

Orientadora: Profa. Dra. Maria Helena Palucci Marziale 
AUTORIZO A REPRODUÇÃO E DIVULGAÇÃO TOTAL OU PARCIAL DESTE ESTUDO, POR QUALQUER MEIO CONVENCIONAL OU ELETRÔNICO PARA FINS DE ESTUDO E PESQUISA, DESDE QUE CITADA A FONTE.

\section{FICHA CATALOGRÁFICA}

Sebastião, Barbara Aparecida

Efeitos adversos na saúde de cirurgiões dentistas.

Ribeirão Preto, 2007.

$72 \mathrm{f} . . ; 30 \mathrm{~cm}$.

Dissertação de Mestrado apresentada à Escola de Enfermagem de Ribeirão Preto/USP - Área de Concentração: Enfermagem Fundamental - Linha de Pesquisa: Saúde do Trabalhador.

Orientador: Marziale, Maria Helena Palucci..

1. Efeitos adversos. 2. Cirurgiões dentistas. 3. Equipamentos motores. 4. LER. 5. DORT.. 


\section{FOLHA DE APROVAÇÃO}

Barbara Aparecida Sebastião

Efeitos adversos na saúde dos cirurgiões-dentistas e suas correlações com o uso de equipamentos motores

Dissertação apresentada à Escola de Enfermagem de Ribeirão Preto da Universidade de São Paulo para obtenção do título de Mestre em Enfermagem Fundamental

Data da defesa:

\section{Banca Examinadora}

Nome:

Título:

Instituição:

Julgamento:

Assinatura:

Nome:

Título:

Instituição:

Julgamento:

Assinatura:

Nome:

Título:

Instituição:

Julgamento:

Assinatura: 


\section{DEDICATÓRIA}

À Minha Família que há muito tem compreendido e apoiado minha dedicação para com os estudos.

Aos meus amigos que sempre estiveram ao meu lado, prestando incentivo e, muitas vezes, contribuindo para a realização desta obra. 


\section{AGRADECIMENTOS}

A Deus, por permitir que todos os meus objetivos tenham sido concretizados até aqui.

À minha orientadora Profa. Dra. Maria Helena Palucci Marziale que desde o início tem me incentivado nessa caminhada e me ensinado a trilhar o árduo caminho da pesquisa.

Ao Prof. Dr. Vanderlei José Haas que demonstrou cautela, generosidade e dedicação não só no tratamento estatístico deste estudo, mas ao lidar com nossas emoções nos momentos mais difíceis.

À Profa. Dra. Maria Lúcia do Carmo Cruz Robazzi que muito me atendeu nas dúvidas com esclarecimentos, dedicação e carinho.

Às demais Profas. dessa Escola que em determinadas oportunidades em disciplinas e reuniões científicas opinaram e realizaram sugestões para este estudo, enriquecendo-o.

À minha Família pelo amor e carinho dedicados a mim em todos estes anos, e principalmente, nessa fase da minha vida.

Aos meus Amigos, em especial à cirurgiã-dentista, Dra.Carla Moreto Santos que muito me incentivou e colaborou para a construção desse estudo.

Aos cirurgiões-dentistas de Ribeirão Preto que, voluntariamente, participaram do presente estudo e que, muitas vezes, sugeriram outros aspectos a serem abordados em estudos futuros.

À CAPES pela concessão de bolsa de mestrado.

Enfim, a todos aqueles que, de alguma forma, contribuíram para a realização deste estudo. 


\section{SUMÁRIO}

RESUMO

ABSTRACT

RESUMEN

LISTA DE FIGURAS

LISTA DE TABELAS

1. INTRODUÇÃO ........................................................ 1

1.1. Revisão da literatura..................................................... 7

1.1.1. A relação saúde - trabalho - doença ............................... 7

1.1.2. O cirurgião dentista e os riscos ocupacionais .................. 11

1.1.2.1. Riscos químicos ...................................................... 12

1.1.2.2. Riscos biológicos ...................................................... 13

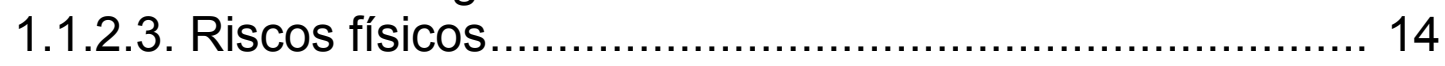

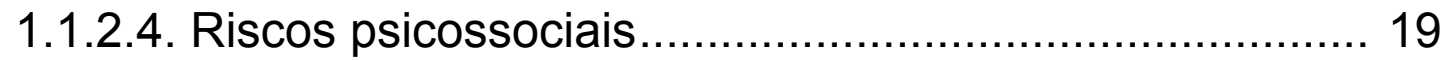

1.1.2.5. Riscos ergonômicos ............................................... 20

1.1.3. Considerações a respeito das LER/DORT ...................... 21

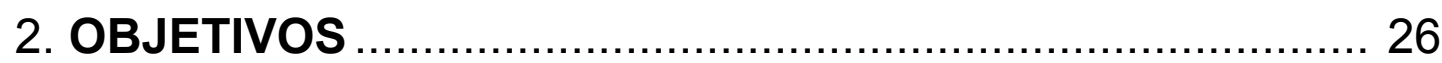

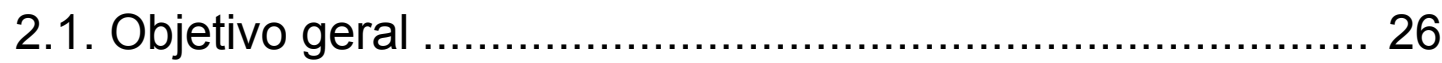

2.2. Objetivos específicos.................................................... 26

3. METODOLOGIA ..................................................... 27

4. RESULTADOS E DISCUSSÃO ….................................... 32

5. CONSIDERAÇÕES FINAIS .......................................... 56

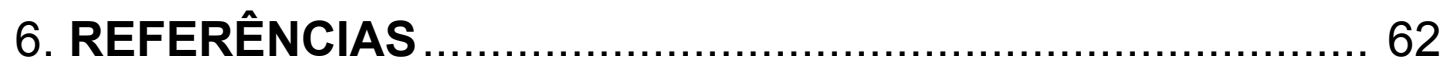

\section{ANEXOS}

Anexo A Comitê de Ética em Pesquisa da EERP/USP

Anexo B Conselho Regional de Odontologia de São Paulo

\section{APÊNDICES}

Apêndice A Questionário de Avaliação

Apêndice B Carta de Esclarecimento

Apêndice C Termo de Consentimento Livre e Esclarecido 


\section{RESUMO}

SEBASTIÃO, B.A. Efeitos adversos na saúde de cirurgiões-dentistas e suas correlações com o uso de equipamentos motores. Ribeirão Preto; 2007. 72 f. Dissertação (Mestrado) - Escola de Enfermagem de Ribeirão Preto, Universidade de São Paulo, 2007.

O objetivo desta pesquisa foi identificar os efeitos adversos relatados por cirurgiões-dentistas (CD) e correlacioná-los com o uso de equipamentos motores. Trata-se de um estudo seccional, não experimental com análise quantitativa dos dados. O estudo foi realizado com 247 CD de Ribeirão Preto-SP. Na coleta dos dados, foi utilizado um questionário auto-aplicável composto por questões agrupadas em: questões sócio-demográficas, relativas a efeitos adversos (musculoesqueléticos, nervosos e vasculares), prática profissional e questões sobre o uso de equipamentos motores. Os dados foram analisados por meio de medidas de distribuição (freqüência), análise bivariada (Teste qui-quadrado e Exato de Fisher) e análise multivariável (Regressão logística). Os efeitos indesejáveis relatados pelos sujeitos e considerados mais intoleráveis foram: dor $(67,65 \%)$, limitação de amplitude de movimento $(7,84 \%)$ e parestesia / formigamento (6,86\%). As regiões do corpo mais acometidas foram: pescoço, ombros e membros superiores direitos, perfazendo $76,8 \%$ das queixas. Os preditores estatisticamente significativos para os efeitos indesejáveis relatados em mãos foram sexo $(R C=0,513, p=0,056)$ e pausa entre os atendimentos $(R C=$ $0,514, p=0,022)$. O equipamento mais utilizado foi o motor de alta rotação $(94,7 \%)$, seguido pelos de baixa rotação com contra-ângulo $(82,2 \%)$ e baixa rotação com peça reta $(62,8 \%)$. Concluiu-se que embora os CD apresentassem sintomatologia característica de exposição a equipamentos motores que emitem vibração, estes sintomas não são suficientes para confirmar que os equipamentos motores são prejudiciais a sua saúde e que são fatores de risco para a ocorrência de LER/DORT. Os resultados deste estudo oferecem subsídios importantes para a conscientização do cirurgião-dentista sobre sua prática de trabalho e a necessidade de cuidar de sua saúde e levanta questionamentos que possibilitarão a realização de futuras investigações pela equipe multidisciplinar de Saúde do Trabalhador.

Descritores: Efeitos adversos, cirurgiões dentistas, equipamentos motores, LER e DORT. 


\section{ABSTRACT}

SEBASTIÃO, B.A. Adverse effects on dental surgeons' health and its correlations with motor equipment use. Ribeirão Preto; 2007. 72 p. Master's Thesis University of São Paulo at Ribeirão Preto College of Nursing, 2007.

This study aimed to identify adverse effects reported by dental surgeons (DS) and correlate them to the use of motor equipment. We carried out a non experimental cross-sectional research with quantitative data analysis. The study involved 247 DS who work in Ribeirão Preto, Brazil. A self-applied questionnaire was used to assess the professionals. This instrument consisted of four parts, asking sociodemographic questions, questions about reported (muscle-skeletal, nervous and vascular) adverse effects, professional practice and questions related to motor equipment use. Data were analyzed through distribution (frequency) measures, bivariate analysis (chi-square and Fisher's exact test) and multivariate analysis (logistic regression). Within the described undesirable effects, the ones these professionals considered most intolerable are pain $(67.65 \%)$, movement range limitation $(7.84 \%)$ and paresthesia/tingling $(6.86 \%)$. The most affected body regions were neck, shoulders and right superior limbs, corresponding to $76.8 \%$ of complaints. The reported predictors statically significant for the undesirable effects on hands were gender $(R C=0,513, p=0,056)$ and pause between appointments $(R C=0,514, p=0,022)$. These professionals most frequently used high-speed rotating equipment $(94.7 \%)$, followed low-speed rotation equipment with contraangle $(82.2 \%)$ and low-speed rotation equipment with a straight piece $(62.8 \%)$. Although the symptoms these professionals present are characteristic of exposure to vibrating motor equipment, these symptoms are not sufficient to confirm that motor equipments cause damage to health and are factors of risk to the occurrence of RSI and WMSD. The results of this study offer important support to the consciousness of the Dental Surgeon about his(er) practice and the need to care of his(er) health and raises questions that can give rise to further research by the multidisciplinary team on the worker's health.

Descriptors: Adverse effects, dental surgeons, motor equipment, RSI and WMSD 


\section{RESUMEN}

SEBASTIÃO, B.A. Efectos adversos en la salud de cirujanos dentistas y posibles correlaciones con el uso de equipos motorizados. Ribeirão Preto; 2007. 72 h. Disertación (Maestría) - Escuela de Enfermería de Ribeirão Preto, Universidad de São Paulo, 2007.

La finalidad de este estudio fue identificar los efectos adversos relatados por cirujanos dentistas (CD) y correlacionarlos con el uso de equipos motorizados. Se trata de una investigación no experimental de corte transversal con análisis cuantitativo de los datos. El estudio se realizó con 247 CD de Ribeirão Preto- São Paulo. En la colecta de los datos fue utilizado un cuestionario autoaplicado compuesto por cuatro grupo de preguntas, siendo: preguntas socio demográficas, preguntas relativas a los efectos adversos (músculo-esqueléticos, nervosos y vasculares), práctica profesional y preguntas sobre el uso de equipos motorizados. Los datos fueron analizados a través de medidas de distribución (frecuencia), análisis bivariado (test chi-cuadrado y exacto de Fisher) y el análisis multivariado (Regresión logística). Entre los efectos indeseables descritos fueron: Dolor (67,65\%), limitación de amplitud de movimiento $(7,84 \%)$ y parestesia/hormigueo $(6,86 \%)$. Las regiones del cuerpo más comprometidas fueron: cuello, hombros y miembros superiores derechos componiendo un porcentaje del $76,8 \%$ de las quejas. Los predictores estadísticamente significativos para los efectos indeseables en manos fueron: sexo $(R C=0,513, p=$ $0,056)$ y pausa entre las atenciones $(R C=0,514, p=0,022)$. El equipo más utilizado fue el motor de alta rotación $(94,7 \%)$, seguido por el de baja rotación con contra-ángulo $(82,2 \%)$ y el de baja rotación con pieza recta $(62,8 \%)$. Se concluyó que, aunque los $C D$ presentan sintomatología característica de exposición a equipos motorizados que emiten vibración, estos síntomas no son suficientes para confirmar que los equipos motorizados son perjudiciales para la salud y que son factores de riesgo para la ocurrencia de LER/DORT. Los resultados de este estudio ofrecen subsidios importantes para concientizar a los CD sobre su práctica de trabajo y la necesidad de cuidar su salud, y levanta cuestiones que posibilitaran realizar futuras investigaciones por el equipo multidisciplinar de salud del trabajador.

Descriptores: Efectos adversos, cirujanos dentistas, equipos motorizados, LER y DORT 


\section{LISTA DE FIGURAS}

Figura 1 Freqüências dos efeitos intoleráveis osteomusculares, nervosos e

página vasculares relatados por cirurgiões dentistas de Ribeirão Preto, São Paulo, 2006

Figura 2 Percentual das regiões do corpo mais relatadas pelos efeitos indesejáveis osteomusculares, nervosos e vasculares nos cirurgiõesdentistas segundo o Questionário Nórdico de Lesão osteomuscular (PINHEIRO et al., 2002). Ribeirão Preto, São Paulo, 2006.

Figura 3 Freqüência relativa dos tipos de tratamentos realizados por cirurgiões dentistas em função do efeito intolerável relatado. Ribeirão Preto, São Paulo, 2006 


\section{LISTA DE TABELAS}

Tabela 1. Distribuição dos cirurgiões dentistas segundo características sócio-demográficas. Ribeirão Preto, São Paulo, 2006...

página

Tabela 2. Distribuição dos cirurgiões-dentistas segundo características comportamentais (prática de atividade física regular e regiões do corpo mais recrutadas durante a prática) avaliadas de acordo com o critério: sexo. Ribeirão Preto, São Paulo, 2006.

Tabela 3. Caracterização das variáveis ocupacionais dos cirurgiões dentistas segundo o tempo de trabalho, horas diárias trabalhadas, dias trabalhados por semana e realização de pausas entre os atendimentos. Ribeirão Preto, São Paulo, 2006.

Tabela 4. Caracterização das variáveis ocupacionais dos cirurgiõesdentistas, segundo os procedimentos mais realizados em suas rotinas de trabalho. Ribeirão Preto, São Paulo, 2006

Tabela 5. Efeitos adversos osteomuscular, nervoso e vascular relatados pelos cirurgiões-dentistas ao longo do tempo de atuação profissional que persistiram por tempo determinado ou vem persistindo no último ano. Ribeirão Preto, São Paulo, 2006.............

Tabela 6. Resultado da Regressão logística obtido através do SPSS versão 15.0 tendo como preditores: sexo, idade, prática de atividade física regular, tempo como cirurgião dentista e realização de pausa entre os atendimentos associados com o surgimento de efeito indesejável no último ano.

Tabela 7. Resultado da Regressão logística obtido através do SPSS versão 15.0 tendo como preditores apenas as variáveis que apresentaram significância estatística (sexo e realização de pausa entre os atendimentos) associados com o surgimento de efeito indesejável no último ano, freqüência dessas variáveis e valor de $p$, sendo $p \leq$ 0,05 .

Tabela 8. Resultado da Regressão logística obtido através do SPSS versão 15.0 tendo como preditores: sexo, idade, prática de atividade física regular, tempo como cirurgião dentista e realização de pausa entre os atendimentos associados com o diagnóstico de LER/DORT auto-relatado.

Tabela 9. Resultado da Regressão logística obtido através do SPSS versão 15.0 tendo sexo como o único preditor que apresentou significância estatística associado com 0 diagnóstico de LER/DORT auto-relatado, freqüência dessa variável e valor de $p$, sendo $p \leq 0,05$. 
Tabela 10 Correlação entre o uso de equipamentos motores de alta e baixa rotação com sintomatologia auto-relatada em mãos de CD e relação do tempo de uso desses equipamentos pelos profissionais. 


\section{EFEITOS ADVERSOS NA SAÚDE DE CIRURGIÕES-DENTISTAS E SUAS CORRELAÇÕES COM O USO DE EQUIPAMENTOS MOTORES}

\section{INTRODUÇÃO}

O cirurgião-dentista $(C D)$ é um profissional que há muito sofre com agravos ocupacionais, tanto de ordem física como psíquica (NOGUEIRA, 1983; COSTER; CARTSTENS; HARRIS, 1987; MANDEL, 1993; LOPES; VILLANACCI NETO, 1994; MEDEIROS; RIUL, 1994). Em se tratando dos principais agravos à saúde desses trabalhadores, estudos sistemáticos realizados desde a década de 50 foram os primeiros a identificar as lesões musculoesqueléticas e essas pesquisas foram responsáveis por alterações no processo de trabalho dos cirurgiõesdentistas, inclusive na mudança do trabalho em posição ortostática para a posição sentada (RUNDCRANTZ; JOHNSSON; MORITZ, 1991).

Embora mudanças efetivas tenham sido realizadas para a melhoria da atuação do profissional odontólogo, percebe-se que muito ainda há de ser feito para a melhoria das condições de trabalho desses profissionais, pois, além de se exporem a fatores de riscos químicos, biológicos, físicos, radiativos, ergonômicos e posturais, sofrem com a instalação de problemas osteomusculares em decorrência da interação de alguns fatores acima relacionados.

Atualmente, os cursos de Odontologia possuem, obrigatoriamente, em seus currículos, disciplinas que englobam o conteúdo relativo às causas das Doenças Osteomusculares Relacionadas ao Trabalho (DORT) e sua prevenção sob o enfoque ergonômico. Geralmente, o conteúdo abordado nessas disciplinas é básico e voltado para o estudo de posições de membros inferiores, tronco e 
membros superiores mais adequadas para o trabalho clínico; no entanto, os movimentos finos realizados com as mãos e punhos são superficialmente abordados (PERRI DE CARVALHO, 2001).

Dessa forma, tem-se que questões relativas a outros fatores predisponentes à ocorrência de DORT, como equipamentos motores e sintomatologia mais específica, como as neurovasculares, ainda são pouco enfocadas em conteúdos disciplinares da graduação. Tal fato pode manter velados outros fatores que podem aumentar insidiosamente o risco desse profissional da saúde a desenvolver uma DORT e, com isso, contribuir para a má qualidade de vida desse profissional (MICHELIN; LOUREIRO, 2000; MANSFIELD, 2005).

Alguns estudos foram realizados para verificar a prevalência de sintomas em cirurgiões-dentistas e trouxeram queixas mais minuciosas que extrapolam estruturas osteomusculares e já descrevem lesões articulares, vasculares e nervosas (STOCKSTILL et al., 1993; NAKLÁDOVÁ et a.I, 1995; SZYMMANSKA, 2001; ALEXOPOULOS; STATHI; CHARIZANI, 2004). Tais estudos questionam a influência da exposição a alguns equipamentos motores (que emitem vibração), a influência de algumas especialidades que requisitam dos profissionais a execução de determinados procedimentos específicos (protesistas) e não apenas a de movimentos repetitivos, posições estáticas e antianatômicas adotadas.

Com relação a regiões do corpo mais acometidas pela prática da profissão, a maioria das investigações realizadas com CDs relata queixas em região cervical, membros superiores (mãos) e ombros, descrevendo não somente dor (SANTOS FILHO; BARRETO, 2001; NADER, 2006) como efeito adverso, mas também parestesia, formigamento e perda de controle motor. 
Em estudo realizado na Grécia, foram investigadas as associações entre características pessoais, desgaste físico, fatores psicossociais e estado geral de saúde de cirurgiões-dentistas com danos em coluna vertebral, ombros e membros superiores e esse mesmo estudo verificou a correlação entre as queixas dessas estruturas musculoesqueléticas e seus efeitos sobre as associações entre os fatores de risco e a ocorrência dessas lesões. Os autores desse mesmo estudo relatam que poucas pesquisas são realizadas com essa finalidade e com esse grupo de profissionais (ALEXOPOULOS; STATHI; CHARIZANI, 2004).

Embora estudos com CD brasileiros descrevam a prevalência de $58 \%$ de dor musculoesquelética em uma ou mais regiões do segmento superior do corpo (SANTOS FILHO \& BARRETO, 2001), e que CD do Nebraska relatem uma prevalência de que $29 \%$ deles sofrem com dor, parestesia e formigamento em mãos, braços e região cervical (STOCKSSTILL et al., 1993), considera-se que outros estudos devam ser realizados para que se verifiquem correlações entre o uso de equipamentos motores e a manifestação de sintomatologia e agravos à saúde (relacionados ao sistema vascular, nervoso e osteomuscular) nesses profissionais.

Sendo assim, a realização de uma nova pesquisa com esses profissionais não desconsiderará a importância das melhoras ergonômicas, da adequação das posturas de trabalho, nem mesmo das discussões sobre novas medidas de prevenção, mas realizará um estudo com a tentativa de correlacionar efeitos adversos descritos na literatura com possíveis fatores de risco, até então, pouco mencionados dentro desse grupo de profissionais. 
Para Egri (1999), além da questão relativa à incipiente formação no que se refere à relação saúde-doença dos cirurgiões-dentistas, esses profissionais enfrentam o problema pela falta de apoio à classe odontológica por parte das seguradoras de saúde que ainda não consideram algumas lesões que podem ser causadas pelo uso repetitivo dos instrumentos vibratórios e posturas inadequadas como justificativas para afastamento do trabalho.

A referida autora descreve que, de acordo com o Decreto $n^{\circ} 2.172$, de cinco de março de 1997, que regulamenta os benefícios da Previdência Social, doenças degenerativas não produzem incapacidade laborativa; dessa forma, tal decreto confirma que determinados trabalhadores, dentre eles cirurgiõesdentistas, podem vir a enfrentar problemas trabalhistas ao serem desprovidos de amparo legal frente a esse tipo de lesão.

\section{Justificativa do estudo}

Diante do contexto ora descrito, este trabalho de dissertação tem por finalidade investigar quais os efeitos adversos ${ }^{1}$ mais relatados por essa classe de profissionais e correlacionar tais efeitos com o uso de equipamentos motores (equipamentos odontológicos), e, dessa forma, verificar se o uso desses equipamentos no cotidiano dos dentistas pode ser considerado como mais um fator predisponente na ocorrência de doenças ocupacionais, como as Lesões por Esforços Repetitivos (LER) ou Doenças Osteomusculares Relacionadas ao Trabalho (DORT).

\footnotetext{
${ }^{1}$ Efeitos nocivos, colaterais, indesejáveis. Usados com drogas, elementos químicos ou agentes biológicos em dosagem aceitável - ou com agentes físicos e manufaturados em uso normal - para procedimentos diagnósticos, profiláticos, terapêuticos ou anestésicos. Usados também para efeitos adversos ou complicações para efeitos diagnósticos, terapêuticos, profiláticos, anestésicos, cirúrgicos e outras, mas exclui contraindicações, para o qual/ contra-indicações é usado. Somente qualificador; inclui efeitos injuriosos, efeitos indesejáveis, efeitos colaterais em uso normal, para complicações seguindo vários procedimentos.
} 


\section{Resultados Esperados}

A presente pesquisa permitirá que outros fatores predisponentes às lesões ocupacionais (LER/DORT), tais como o uso de equipamentos odontológicos, sejam evidenciados e passem a ser vistos de forma criteriosa pelos profissionais da saúde, fabricantes e profissionais usuários.

O estudo também possibilitará a verificação, bem como a proposta de fiscalização, no tocante ao uso dos equipamentos odontológicos em consultórios dentários no que tange a suas condições adequadas de uso e tempo de vida útil, dentre outros fatores de igual importância.

Os efeitos adversos descritos na literatura como sendo seqüelas da exposição à vibração tais como: parestesia, formigamento, perda de controle motor das mãos em função do uso dos equipamentos motores poderão ser confirmados ou refutados em investigações minuciosas futuras.

O presente estudo poderá levantar inquietações quanto à correlação entre os sintomas relatados pelos $C D$ e o uso de equipamentos odontológicos que emitem vibração, e a partir daí, promover intervenção com o intuito de comprovar a correlação estabelecida em estudos prévios descritivos, tal como este.

O estudo em questão proporcionará a elaboração de relatório de pesquisa apontando hipóteses e possíveis sugestões no que diz respeito aos efeitos adversos e suas possíveis correlações com o uso de equipamentos motores e a publicação de artigos científicos.

\section{Impacto Científico}

Embora uma celeuma ainda envolva a questão da influência dos equipamentos motores no sistema mão-braço de cirurgiões-dentistas, a presente 
pesquisa permitirá que estudos futuros explorem questões minuciosas no que tange à influência desses equipamentos odontológicos que emitem vibração, estabelecendo parâmetros de tempo de uso diário e limites de freqüência de vibração para os mesmos. Dessa forma, os produtos deste estudo tornar-se-ão disparadores críticos para a discussão dos efeitos adversos (musculoesqueléticos e neurovasculares) até então relatados por esses profissionais.

\section{Impacto Tecnológico}

O estudo possibilitará discussões a respeito do uso de equipamentos motores por cirurgiões-dentistas e a verificação e características como tamanho, peso, design e freqüência emitida por eles como sendo alguns dos fatores predisponentes para que esses equipamentos tornem-se colaboradores no desencadeamento de determinados efeitos adversos como parestesia/ formigamento, perda de sensibilidade tátil, limitação de amplitude de movimento, redução de força de preensão palmar, dentre outros.

\section{Impacto Econômico}

Em se tratando do presente estudo, a elaboração de programas educativos para orientar profissionais odontólogos quanto ao uso de equipamentos motores pode ser tomada como mais uma medida preventiva com o intuito de minimizar a ação dos efeitos adversos na saúde dos profissionais odontólogos. Outra providência relevante é a adoção de posturas físicas adequadas no ambiente de trabalho. Embora esta tenha sido uma das mais citadas em estudos já realizados com essa classe de profissionais, tais posturas tornar-se-ão mais praticáveis se vierem acompanhadas de readaptações do mobiliário odontológico, mudanças 
que devem ser reestruturadas pelos fabricantes de tais equipamentos. Outra medida que poderia ser reavaliada é a inserção de tópicos mais específicos na disciplina de ergonomia ofertada à graduação no que tange à exposição a outros fatores predisponentes às LER/DORT tais como o uso de equipamentos odontológicos motores.

\subsection{Revisão da Literatura}

\subsubsection{A relação saúde - trabalho - doença}

Historicamente, o trabalho possui diversos significados e sua análise tem interessado a vários filósofos e cientistas sociais e estudiosos de várias áreas do saber (ARENDT apud PENNELA, 2000). A palavra trabalho não é sinônimo de labor, pois esta traz uma conotação de dor e luta do homem contra a necessidade, enquanto aquela está relacionada ao esforço positivo e à produção. Todavia, na Grécia Antiga ambos os termos se referem a situações degradantes, penosas e humilhantes a que eram submetidas mulheres e escravos, impedidos de demonstrarem suas virtudes.

A autora citada também relata que, de acordo com a tradição judaico-cristã, o trabalho era considerado bênção de Deus e por meio dele o homem deveria sentir a satisfação de estar vivo e ser capaz de deixar sua marca permanente no mundo como legado a todas as suas gerações vindouras. Nesse sentido, o trabalho ligava os seres humanos à fertilidade, à produtividade e aos ritmos da natureza (esforço, gratificação, produção e consumo), sendo esse, fonte de prazer e felicidade. 
Segundo Pennella (2000), particularmente para Marx, o trabalho produz vida e, portanto, é a atividade essencial ao desenvolvimento humano e sua realização que passou a ser visto como a capacidade humana de construir o mundo. O primeiro fato histórico, segundo o autor, é a produção dos meios para a satisfação das necessidades materiais dos seres humanos. Para isso, eles deveriam interagir com a natureza e com outros indivíduos e, nesse processo, os homens recriam a si próprios.

Em se tratando da ética protestante, o trabalho produziu os trabalhadores disciplinados, tão necessários à expansão racional da economia capitalista. Após esse impulso inicial, o capitalismo libertou-se dessa orientação religiosa, passando a vê-la como uma influência prejudicial sobre a economia.

Segundo Pennella (2000), o trabalho é entendido atualmente como uma invenção da modernidade, como um produto da industrialização e governado pelas regras da racionalidade econômica. A convergência entre as noções de trabalho e virtude e o estabelecimento de uma ética protestante do trabalho definiu um tipo de cidadão trabalhador que, subseqüentemente, viria a tipificar a cidadania moderna e a desenvolver novas formas de organização social.

De acordo com a linha de pensamento moderna, o trabalho influencia as atividades extrajornada, exerce influência marcante nas atitudes morais e intelectuais, nas opiniões e motivações, constituindo a identidade de quem trabalha.

Os estudos sobre a relação trabalho-doença eram pouco conhecidos na Idade Média, estando as primeiras observações registradas em problemas de saúde provocados pela atividade extrativa mineral. Essa preocupação se deu pela importância de uma nação que se traduzia pela quantidade de metais que extraía. 
Dentro desse contexto, em 1556 e em 1567, respectivamente, Georgius Agrícola e Theophrastus Von Hohenheim realizaram estudos sobre doenças dos mineiros e metalúrgicos (MUROFUSE, 2000).

Com o intuito de facilitar o encaminhamento das medidas de prevenção e controle de doenças dos trabalhadores, utilizou-se a nomenclatura "agentes etiológicos específicos" (químicos, físicos e biológicos de origem ocupacional) para substituir as até então utilizadas, "bactérias e vírus" (MUROFUSE, 2000).

Embora essa nomenclatura tenha sido utilizada com o intuito de facilitar o encaminhamento das medidas de prevenção e controle das doenças, Mendes (1995) afirma que, além de não ter facilitado a prevenção, tal atitude prestou-se para escamotear outras dimensões da natureza do problema, refletindo a ideologia prevalente e, ao mesmo tempo, alimentando-a.

Porém, ao analisar as doenças dos trabalhadores, não basta interpretar que doença se trata de apenas uma ruptura do processo fisiológico que, de forma simplista, pode ser solucionada por uma intervenção clínica; há necessidade de se identificar os determinantes sociais, quer de natureza estrutural, como o modo de produção, quer de natureza localizada no próprio processo de trabalho. Porém, esta forma de compreender a doença ainda hoje é pouco aplicada, pois determinados médicos não confrontam os métodos de produção capitalista com os fatores lesivos à saúde (MENDES, 1995).

Murofuse (2000) relata que a doença é considerada um atributo da vida, constituindo-se em um processo biológico tão antigo quanto a mesma. Sendo assim, a relação saúde-doença consiste na expressão da instabilidade a que um organismo vivo está exposto no mundo em constante mudança. Desta maneira, as causas das doenças, como fenômeno biológico, são buscadas no reino da 
natureza. Porém, quando se refere a humanos, da mesma forma que o trabalho resvala nas atividades extrajornada, conforme relatado anteriormente, a doença resvala em condições extra natureza-pura, sendo mediada e modificada por questões sociais, pelo ambiente cultural que a atividade cria.

Gomez-Minayo e Thedin-Costa, (1997) relatam que nem sempre as doenças adquiridas no ambiente de trabalho apresentam sintomas que as diferenciam de outras patologias. Dessa forma, fica difícil para a Medicina do Trabalho identificar processos danosos à saúde que não tenham nexo claro com a exposição a um agente exclusivo.

A Medicina do Trabalho, ao isolar riscos específicos, atua sobre suas conseqüências medicalizando em função de sinais e sintomas ou associando-os a uma doença legalmente reconhecida. Dessa forma, não é capaz de superar o enfoque biológico e ignora outros fatores que envolvem as relações psicossociais que trazem conseqüências à saúde do trabalhador (GOMEZ-MINAYO; THEDINCOSTA, 1997).

Em relação ao adoecimento pelo trabalho, Teixeira (2003) relata que é necessário perceber quem é o trabalhador que adoece e de que forma ele está inserido no processo produtivo. A intervenção somente no corpo não é suficiente para um diagnóstico que formule terapêuticas eficazes, diante dos milhares de casos de doenças decorrentes de ambientes insalubres e de processos de trabalho mal dimensionados.

Ao se estender esses conceitos para trabalhadores odontólogos, verifica-se que esses profissionais há muito vem sendo estudados. Estudos descritivos têm levantado questões a respeito de doenças ocupacionais em decorrência de aspectos ergonômicos, posturais e auditivos, mas é escassa a literatura no que 
tange a aspectos biopsicossociais desses profissionais. Segundo Michelin e Loureiro (2000), a falta de organização no ambiente de trabalho desses profissionais poderá resultar em desgastes físicos, comprometendo assim sua produtividade.

Com relação à sintomatologia relatada por esses profissionais, essa não define o objeto causal de tais efeitos adversos relatados e, dessa forma, esses efeitos tornam-se escamoteados por não serem questionados a respeito de que fatores ou determinantes de risco podem estar relacionados na ocorrência de determinadas enfermidades.

Essa discussão já foi mencionada por Gomez-Minayo e Thedin-Costa, (1997) e é ela que nos traz uma inquietação para investigar o efeito dos equipamentos motores sobre as estruturas osteomusculares, vasculares e nervosas de cirurgiões-dentistas e seus possíveis efeitos adversos causados devido à exposição à vibração mecânica emitida por tais equipamentos odontológicos.

\subsubsection{Os cirurgiões-dentistas e os riscos ocupacionais}

Considerando-se que situação ou fator de risco é uma condição ou conjunto de circunstâncias que têm potencial para causar um efeito adverso, lesões, danos à saúde, doenças ou até a morte à propriedade ou ao meio ambiente, essas situações ou fatores de risco para a saúde e segurança dos trabalhadores, presentes ou relacionados ao trabalho, podem ser divididos em cinco grandes grupos: químicos, biológicos, físicos, ergonômicos e mecânicos e de acidentes (PERNAMBUCO, 2001). 
Em se tratando de CD, Nogueira (1983) descreve que existe em toda atividade um risco permanente de exposição aos acidentes de trabalhos aos quais esses profissionais estão expostos, sendo esses dos mais variados tipos. Este trabalho requer dos profissionais ações minuciosas que exigem coordenação motora, raciocínio, discernimento, paciência, habilidade manual, destreza, força muscular e bom posicionamento físico dentre outros.

Segundo Faria (2003), existe uma celeuma relacionada a alguns fatores de risco que não conseguem ser avaliados apenas por dados quantitativos; sendo assim, são mais efetivamente "sentidos" do que medidos; é o caso de reações estressogênicas, nas quais alguns sinais vitais como freqüência cardíaca e pressão arterial dentre outros podem ser medidos, mas representam apenas alguns indicadores do problema.

Essa mesma autora relata que em outras situações, a carência de informações sobre determinados riscos pode impedir a sua percepção, como é o caso da energia vibratória emitida através dos equipamentos manuseados por cirurgiões-dentistas, que podem trazer algum tipo de sintomatologia específica ou não e, dessa forma, camuflar lesões insidiosas que podem se manifestar ao longo dos anos de trabalho nessa função.

\subsubsection{Riscos químicos}

Saquy et al. (1998), em um estudo a respeito de doenças ocupacionais em cirurgiões-dentistas, relatam que muitos são os produtos químicos com os quais esses profissionais lidam em sua rotina de trabalho e que, quando manipulados inadvertidamente, podem causar danos à saúde do profissional. Tais substâncias 
podem penetrar no organismo através das vias aéreas por inalação, por ingestão ou penetrados via epiderme (SALIBA, 2004).

Embora cirurgiões-dentistas expressem processos alérgicos e eczemas devido à manipulação de determinados medicamentos, uso de determinados antisépticos, caso do ácido fênico 2,5 a $5 \%$, uso de luvas de látex, para Saquy et al. (1998) a maior preocupação para esses profissionais é a manipulação do mercúrio, principalmente na preparação da amálgama.

Esse mesmo autor também relata existir uma alta concentração desse produto no organismo desses profissionais e a presença de sintomas insidiosos como irritabilidade, insônia, agitação e sialorréia na vida deles; outros se arriscam a correlacionar a alta concentração desse produto no organismo desses profissionais ao surgimento de Doença de Parkinson e a deficiência renal aguda nos mesmos.

Medidas de cuidado e prevenção (tipo de piso ideal para o consultório, claro e impermeável, utilização de luvas de vinil ao invés de látex, cuidados especiais com o uso e manutenção do amalgamador, bem como com o processo de confecção da amálgama e restrição aos produtos alérgicos para evitar os processos de dermatites e alergias) devem ser tomadas para evitar contaminação com o mercúrio.

\subsubsection{Riscos biológicos}

Consideram-se agentes biológicos, bactérias, fungos e vírus dentre outros parasitas. Segundo Saliba (2004), a exposição a agentes biológicos ocorre em

diversos ambientes ocupacionais, dentre eles, ambulatórios, laboratórios e hospitais. 
Quanto aos profissionais odontólogos, embora os riscos sejam conhecidos desde a década de 30 , medidas de controle efetivas só foram tomadas a partir da década de 80 com o advento da AIDS e mais especificamente com o seu agente etiológico, o HIV (GARCIA; BLANK, 2006).

No atendimento odontológico, o uso de alguns equipamentos motores favorece a ocorrência de respingos e o uso de materiais perfurocortantes propicia lesões percutâneas nos profissionais (GRAZIANO et al., 2000). Outro fator não menos importante é a própria posição do paciente e do profissional que podem contribuir para a ocorrência de acidentes biológicos (RAMOS-GOMES et al., 1997).

Como medidas de controle e prevenção de infecção na prática odontológica, o Ministério da Saúde do Brasil incorpora os conceitos das Precauções Universais e Precauções Padrão as quais incluem o uso de EPIs (equipamentos de proteção individual - luvas, jaleco, óculos de proteção, máscara e gorro), a fim de prevenir o contato da pele e membranas mucosas do profissional com material biológico dos pacientes (GARCIA; BLANK, 2006).

\subsubsection{Riscos físicos}

Segundo Saliba (2004), os agentes físicos são formas de energia às quais os trabalhadores podem estar expostos como ruído, vibração, pressão anormal, temperaturas extremas, radiações ionizantes, bem como infra e ultra-som. No presente estudo, ater-nos-emos apenas ao enfoque da vibração como fator de risco físico.

Kroemer e Grandjean (1997) definem que vibrações são oscilações de massa em torno de um ponto fixo. Elas são produzidas por qualquer movimento 
periódico regular ou irregular produzido por equipamentos, veículos ou outro mecanismo em contato com o corpo humano que o tire de sua condição de repouso.

Os mesmos autores relatam que o som é a forma de vibração que afeta nossas células auditivas e as vibrações mecânicas são aquelas que podem causar alterações físicas e orgânicas no organismo humano; são essas as de interesse no presente estudo. Esses autores relatam também que devido à diferença dos segmentos corporais em relação às suas constituições, os danos ocorrem de maneira diferente dependendo da estrutura exposta.

Segundo os critérios propostos pela Occupational Exposure to Hand - Arm Vibration: Criteria for a Recommended Standard (NIOSH, 1989), "é demonstrado que a presença de desordens relacionadas com o efeito da vibração afetam as respostas subjetivas individuais, como a percepção da vibração direcionada às mãos; estas desordens não podem ter seus efeitos mensurados sobre as características da resposta vibratória da mão".

Radwin; Armstrong; Chaffin (1987) relata que a vibração pode afetar a performance dos trabalhadores que lidam com o equipamento vibratório e levar a riscos de trauma. Com o aumento da exposição à vibração, aumenta-se a força de preensão para segurar o equipamento, diminuindo a sensibilidade tátil.

Nakládalová et al, (1995) descreve em seu estudo realizado com técnicos odontólogos que, durante a preensão do instrumento, pequenos músculos da mão mantêm-se vigorosamente contraídos para manter o objeto. A mão desenvolve então uma força reativa para manter o objeto durante o trabalho, o que acaba levando à fadiga desses músculos. 
As evidências científicas comprovam que a exposição à vibração causa vasoespasmo digital e sintomas sensorioneurais, como parestesia e/ou formigamento nos dedos e/ou desordens músculo-esqueléticas, como redução da força muscular, fadiga e diminuição da resistência (NECKING, 2003).

A dose de vibração recebida por trabalhadores que lidam com instrumentos vibratórios pode ser irreversível e a desordem é geralmente progressiva com o aumento da exposição à vibração. Essa exposição pode trazer conseqüências em mãos e braços de trabalhadores durante sua vida (COCK et al, 2000; CEDERLUND; NORDENSKIÖLD; LUNDBORG, 2001).

Segundo a lista de Doenças Relacionadas ao Trabalho (elaborada em cumprimento à Lei Federal $n^{\circ} 8.080 / 1990$ - inciso VII, parágrafo $3^{\circ}$ do artigo $6^{\circ}$ disposta segundo a taxonomia, nomenclatura e codificação da CID - 10), a vibração é fator de risco para afecções dos músculos, tendões, ossos, articulações, vasos sanguíneos periféricos ou dos nervos periféricos e diversas doenças podem ser desenvolvidas tendo como a vibração um agente etiológico.

Segundo essa mesma lista, em se tratando de extremidades superiores, Síndrome de Raynaud, Acrocianose e Acroparestesia, Dor Articular, Fibromatose da Fáscia Palmar (Contratura ou Moléstias de Dupuytren), dentre outras moléstias, são algumas das enfermidades que a exposição à vibração pode vir a desenvolver.

Síndrome da Vibração mão-braço tem sido observada em trabalhadores que usam instrumentos transmissores de energia vibratória em mãos e braços num maior nível de aceleração. Este nível de aceleração por instrumentos é influenciado por muitos fatores incluindo tipo e peso do instrumento, velocidade 
de manuseio, condições ergonômicas para uso do instrumento, condições ambientais, uso de materiais antivibratórios, etc. (NIOSH, 1989).

Dessa forma, a NIOSH (National Institute for Occupational Safety and Health) não pode estabelecer a quantidade específica de limite de exposição que eliminaria o risco de desenvolver HAVS (Hand-Arm vibration syndrome) em trabalhadores expostos à vibração em mão e punho, nem mesmo quais os tipos de instrumentos são mais lesivos, mas recomenda que a exposição à vibração deva ser reduzida ao mais baixo nível possível de aceleração e tempo de exposição (NIOSH, 1989).

Com relação aos efeitos fisiológicos da vibração, evidências científicas sugerem que a exposição em curtos períodos causa efeitos de pouca significância prática e os efeitos a longos períodos de exposição ainda estão pouco claros (SANDERS, Mc CORMICK, 1987). Estudos epidemiológicos realizados com motoristas de caminhão e operadores de equipamentos pesados revelam que esses trabalhadores possuem incidências desproporcionais de desordens da coluna lombar, hemorróidas, hérnias e problemas digestivos e urinários.

O conhecimento a respeito da vibração e sua conseqüência nas estruturas articulares são ainda escassos, mas sabe-se que ela promove aumento da tensão muscular devido à exposição. Percebe-se também que não é estabelecido tempo determinado ao se referir a curtos e longos períodos de exposição; dessa forma, ainda prevalece uma lacuna ao se estabelecer com quanto tempo de exposição o trabalhador fica vulnerável aos efeitos adversos causados por esse fator de risco.

Para Mansfield (2005), Doença da vibração mão-braço engloba desordens como Síndrome do Túnel do Carpo, que pode ocorrer na ausência de exposição à vibração. Equipamentos de mão que não exibem um bom design podem requisitar 
um esforço maior desse profissional, levar à fadiga muscular e acelerar o processo de lesão. Percebe-se, assim, que há uma junção de fatores que predispõem esse profissional a determinadas lesões que ainda não podem ser caracterizadas por fatores de riscos isolados.

Alterações no sistema osteoarticular das mãos são comuns e resultam de exposição com freqüências abaixo de $30 \mathrm{~Hz}$. A dinâmica das alterações ocorre no curso da exposição ocupacional e é geralmente insidiosa. Alterações no espaço articular, bem como no periósteo e na textura óssea são verificados Szymanska (2001).

Esse mesmo autor relata que efeitos negativos decorrentes da vibração local ocorrem entre 5-1400 Hz, mais precisamente abaixo de $16 \mathrm{~Hz}$. Quanto aos cirurgiões-dentistas, instrumentos de alta e baixa rotação provocam vibração local, ou seja, diretamente nas mãos desses profissionais e os sintomas (esbranquiçamento digital, parestesia, formigamento, dor) perduram por 20 a 45 minutos após o uso dos equipamentos e, quando expostos concomitante ao frio, podem perdurar por horas após o uso.

Pesquisas revelam que esses sintomas relatados não são prevalentes apenas em CD, mas também em engenheiros, trabalhadores florestais, de fábricas de sapato, de indústria de mineração e metalurgia, e que sintomas como esbranquiçamento digital são comuns em trabalhadores que lidam com equipamentos de baixa freqüência o que não ocorre com equipamentos odontológicos. Dessa forma, outros fatores de risco podem estar atuando concomitantemente à vibração no desencadeamento dessa mesma sintomatologia nos CD. 
De acordo com a Diretiva Européia de vibração, os equipamentos motores odontológicos são dominados por alta freqüência (em torno de $1000 \mathrm{~Hz}$ ) e a emissão de freqüência danosa por esses equipamentos é muito baixa. Dessa forma, a mensuração desses equipamentos seria desnecessária embora a Diretiva sugira a minimização da exposição aos riscos provocados pela vibração, com a redução do tempo de uso e o aproveitamento mais eficiente de tais equipamentos (MANSFIELD, 2005).

No Brasil, a Norma Regulamentadora do Ministério do Trabalho e do Emprego NR - 15 anexo 8, faz referência à necessidade de medição da vibração emitida por equipamentos, mas não faz menção ao cuidado com os equipamentos odontológicos.

Szymanska (2002) relata em seu estudo com CD que estes são freqüentemente acometidos por disfunções osteomusculares relacionadas ao trabalho, justamente pela atuação técnica e repetitiva que a profissão exige e pelo campo de visualização restrito ao executar um procedimento clínico na cavidade bucal de um indivíduo. Essa atuação exige do trabalhador o uso de instrumentos com pontas ativas milimétricas e, portanto, uma postura física fechada e contraída. Além disso, alguns instrumentos emitem vibrações mecânicas que podem comprometer a função das extremidades dos membros superiores com as quais estão em contato.

\subsubsection{Riscos psicossociais}

Barreira (1994) evidencia três fatores de risco que atuam concomitantemente na etiologia das patologias, sendo eles os biomecânicos, os administrativos e os psicossociais. Os rodízios de trabalhadores em tarefas 
diferentes, bem como a intensificação das pausas de trabalho e a redução das jornadas e distribuição uniforme das tarefas são condições adequadas de trabalho que podem atuar agravando os três fatores inicialmente citados.

A Organização Mundial de Saúde declarou que os fatores psicossociais são, pelo menos, tão importantes quanto os fatores físicos na prevenção de problemas de saúde entre aqueles que estão expostos a esforços repetitivos (MICHELIN; LOUREIRO, 2000).

Entre os fatores psicossociais encontram-se a percepção de sobrecarga, trabalho monótono, controle limitado das funções, pouca clareza sobre a tarefa e pouco apoio social no trabalho (NIOSH, 1998).

Silverstien et al. (1997) afirma existir influência do ambiente de trabalho no desenvolvimento, exacerbação ou aceleração de um problema físico ou psíquico que vem a culminar com o prejuízo da capacidade de trabalho. Dessa forma, vale ressaltar a importância de outros fatores etiológicos e não só os mecânicos como potenciais agentes etiológicos na ocorrência de enfermidades.

\subsubsection{Riscos ergonômicos}

Observa-se que há muito vem sendo estudada a condição diária do trabalhador odontólogo no que tange aos aspectos ergonômicos. Tais aspectos correspondem, principalmente, ao mobiliário, às posturas físicas de trabalho que são adotadas e à utilização de instrumentos que necessitam da utilização de força manual (REGIS FILHO, 2006).

Flenik et al. (1989) relatam, em um estudo com alunos do curso de graduação em Odontologia do Estado do Paraná, que alterações na postura de trabalho, aparelhagem regulável e móvel, bem como a utilização do moxo e a 
modernização dos equipamentos de mão foram realizadas e os distúrbios relatados anteriormente tiveram suas freqüências diminuídas.

No que diz respeito à questão postural, Michelin e Loureiro (2000), em estudo com cirurgiões-dentistas, relatam que o uso constante dos membros superiores, mais especificamente das mãos, traz doenças específicas, como Dedo em gatilho ${ }^{2}$, Síndrome do Túnel do Carpo $^{3}$ e Tenossinovite de Quervain ${ }^{4}$ dentre outras, e que persiste um desconhecimento do profissional diante dos riscos e implicações sob os quais estão expostos.

Com relação aos equipamentos utilizados na rotina de trabalho dos CD, Pece (1998) relata a inadequação operador/equipamento/instrumento, o que faz com que esses profissionais admitam posturas biomecanicamente traumatogênicas no desempenho da função, trazendo incômodos não somente em membros superiores, mas também em coluna vertebral, cintura escapular e ombros.

\subsubsection{Considerações a respeito das LER/DORT}

As LER/DORT, por definição, são um fenômeno relacionado ao trabalho, caracterizado pela ocorrência de vários sintomas, concomitantes ou não, tais como dor, parestesia, sensação de peso, fadiga, dentre outros. Seu aparecimento é insidioso e acomete geralmente membros superiores, inferiores e coluna cervical. Frequentemente ocasionam incapacidade laboral temporária ou não. São resultantes de superutilização de estruturas anatômicas do sistema músculoesquelético e da falta de tempo de sua recuperação (BRASIL, 2000).

\footnotetext{
${ }^{2}$ Resulta do comprometimento dos tendões flexores profundos dos dedos e do tendão flexor longo do polegar;

${ }^{3}$ Caracteriza-se pela compressão do nervo Mediano em sua passagem pelo canal ou túnel do carpo;

${ }^{4}$ Resulta da constrição da bainha comum dos tendões do abdutor longo e do extensor curto do polegar.
} 
Embora essas lesões constituam problemas de saúde pública atuais em alguns países, as lesões por esforços repetitivos (LER) ou Distúrbios Osteomusculares Relacionados ao Trabalho (DORT) já foram descritas desde o início do século XVIII por Bernardino Ramazzini como doença dos escribas e notários, sendo o primeiro a estabelecer o nexo entre lesão e ocupação (NICOLETTI,1999;LÉO,2000).

Com a Revolução Industrial no século XVIII, o aumento de fábricas e cidades ocasionou transformações sociais profundas nos países, principalmente aquelas relacionadas aos modos e práticas de trabalho, em que as condições de trabalho exaustivas e insalubres tiveram repercussões na saúde e na vida dos trabalhadores dessa época.

Posteriormente, Charles Turner Thackrah (1832), Quervain (1891) e Gray (1893) destacaram como fator comum os movimentos repetitivos e freqüentes de um grupo isolado de músculos de lavadeiras no movimento de torcer o tecido enquanto todo o restante do corpo permanecia por horas em posição estática, sendo estes movimentos descritos como "entorce de lavadeira" (BUSCHINELLI; ROCHA; RIGOTTO, 1993; BAWA, 1997).

Já no século XIX, diversos estudiosos, como Bell (1830), Robinson (1882) e Growers (1888) descreveram a câibra em escrivãos e telegrafistas, reconhecida como uma doença ocupacional. Outros aspectos, não apenas os biomecânicos relacionados ao movimento repetitivo, mas os aspectos relacionados à monotonia já haviam sido relacionados nesses trabalhadores (BAWA, 1997).

O século $X X$ foi o período em que as LER/DORT ganharam maior expressão. No Japão, por volta do início da segunda metade do século, tais lesões foram identificadas em picadores de cartões, operadores de linha de 
montagem, caixas registradoras e operadoras de telefonia. Tal fato culminou com uma diminuição na carga horária de trabalho diária. Na Austrália, nessa mesma época, uma epidemia de dor crônica incapacitava um terço dos trabalhadores, o que representou um gasto de milhões de dólares com tratamentos e indenizações por causas trabalhistas; isso se traduziu no maior problema de saúde pública já visto até então naquele país (EGRI, 1999).

Um grande evento na história da LER ocorreu em 1986, quando, após reunião de consenso, o National Institute of Occupational Safety and Health (NIOSH), nos Estados Unidos, emitiu a seguinte declaração: "Quando as exigências do trabalho... repetidamente excedem a capacidade biomecânica do trabalhador, as atividades tornam-se indutoras de trauma. Portanto, traumatógenas são as fontes de lesão no local de trabalho que afetam o sistema músculo-esquelético". Com esta declaração, o "distúrbio por traumas repetitivos" (DTR), tradução de cumulative trauma disorder (CTD), termo mais utilizado nos Estados Unidos, foi colocado na lista de preocupações nacionais (OLIVEIRA, 1999a).

Segundo Oliveira (2001), as LER/DORT decorrem das relações geradas no processo de trabalho que submetem o trabalhador a inadequadas condições que, além de desencadear adoecimento físico e mental, interferem na sua qualidade de vida. Para compreender a ocorrência das LER/DORT, é preciso analisá-las a partir do processo de produção, na qual as cargas se combinam dinamicamente.

Essa mesma autora relata que a carga fisiológica proveniente da postura incômoda, o trabalho muscular estático, os movimentos repetitivos, a carga psíquica gerada pelo ritmo de trabalho e a pressão de supervisão, entre outros fatores, são um conjunto de cargas que se potencializam entre si no processo de 
produção, realizando a mediação entre o trabalho e o desgaste do trabalhador, levando-o ao adoecimento.

No Brasil, essas lesões foram reconhecidas a partir de 1987 como doenças profissionais por meio da publicação da portaria $n^{\circ} .4 .062$ de 06/08/1987 do quadro de LER e, a partir daí, observou-se um aumento significativo do número de registros dessa doença (COUTO, 1998); em 1998, o Ministério da Previdência e Assistência Social do Brasil designa a terminologia de DORT (Doenças Osteomusculares Relacionadas ao Trabalho) a esse conjunto de lesões (LÉO, 2000). Esta terminologia é muito abrangente, dispensa a relação causal, não exige qualquer explicação quanto ao mecanismo de acometimento, sendo suficiente a relação com o trabalho (OLIVEIRA, 1999b).

As Lesões por Esforços Repetitivos (LER) vêm aumentando significativamente entre a população brasileira. Inicialmente, na década de 80 , fora investigada entre os bancários, mais especificamente, entre os digitadores e em pessoas que exercem atividades em fábricas, trabalhando em posição sentada, porém desempenhando relativo esforço, principalmente em tronco e membros superiores (EGRI, 1999; MICHELIN; LOUREIRO, 2000).

O aumento do número de lesões e sua distribuição entre as diferentes categorias profissionais coincidiram com as mudanças nos processos produtivos promovidas pelas empresas para se adequarem às exigências da economia globalizada e competitiva (OLIVEIRA, 2001).

Considerando o grande número de trabalhadores que são acometidos pelas LER, atualmente denominadas DORT, observa-se uma lacuna das investigações relativa a essa problemática entre cirurgiões-dentistas, categoria profissional que está exposta a variáveis potenciais para ocorrência de DORT, 
tais como: repetição de movimentos de punho, cotovelo, ombro e o uso de instrumental na sua atividade profissional, bem como a existência de alguma influência destes equipamentos devido à emissão de energia mecânica vibratória sobre as extremidades dos membros superiores e que ainda não foram investigados (WILLIAMS; WESTMORLAND, 1994; MICHELIN; LOUREIRO, 2000).

Rempel et al (1992), em um estudo realizado para obter informações sobre a patofisiologia, epidemiologia, evolução clínica, procedimentos médicos e prevenção dos distúrbios por traumas repetitivos em extremidades superiores, verificou que tem sido demonstrado que a força digital aplicada em equipamentos está aumentada em condições de sensação diminuída por exposição das mãos em clima frio, uso de luvas ou uso de instrumentos vibratórios.

Bernard (1997) descreveu que a relação do trabalho com a Síndrome do Túnel do Carpo (compressão do nervo mediano em nível do punho) pode estar associada a movimentos repetitivos, força, posturas desajeitadas de punho e exposição à vibração. Já, Silverstein et al. (1998), conclui que cada condição específica do trabalho também tem sido associada ao princípio de trauma agudo e não somente à exposição de fatores de risco.

\section{Hipótese do estudo}

A utilização de determinados equipamentos motores na prática diária de cirurgiões-dentistas pode ser um fator predisponente à ocorrência de LER/DORT nesses profissionais. 


\section{OBJETIVOS}

\subsection{Objetivo geral}

Identificar os efeitos adversos na saúde de cirurgiões-dentistas e correlacioná-los com o uso de equipamentos motores no trabalho.

\subsection{Objetivos específicos}

- Identificar as características dos cirurgiões-dentistas.

- Caracterizar as atividades de trabalho dos cirurgiões-dentistas.

- Identificar a ocorrência de efeitos adversos à saúde dos cirurgiõesdentistas em decorrência do desempenho de seu trabalho.

- Identificar qual o efeito mais severo, entre os adversos, relatado pelos cirurgiões-dentistas.

- Identificar a ocorrência de LER/DORT diagnosticada entre os cirurgiõesdentistas.

- Correlacionar o uso de equipamentos motores por cirurgiões-dentistas e os efeitos adversos relatados em extremidades superiores pelos mesmos. 


\section{METODOLOGIA}

\section{Tipo de Estudo}

Trata-se de um estudo não-experimental, seccional, com análise quantitativa dos dados.

\section{Local}

A pesquisa foi realizada nos consultórios odontológicos da cidade de Ribeirão Preto - SP.

\section{População}

A população constituiu-se de 1.274 cirurgiões-dentistas domiciliados no município de Ribeirão Preto-SP que possuem registro no Conselho Regional de Odontologia de São Paulo (CRO-SP) no ano de 2006.

\section{Amostra}

Dada a impossibilidade de realizar um estudo censitário, optou-se por uma amostra aleatória simples de cirurgiões-dentistas, empregando-se como grade de amostragem a lista fornecida pelo CRO-SP. Para o cálculo do tamanho da amostra, partiu-se de uma prevalência de $50 \%$ de queixas, com uma precisão de $5 \%$ e um intervalo de confiança de 95\%. Empregando-se o Programa PHSS 2002, obteve-se um número de 298 indivíduos. Para uma perda ou recusa de $15 \%$, o tamanho da amostra final foi de 349 cirurgiões-dentistas.

No entanto, dado o elevado número de recusas, apenas $246 \mathrm{CD}$ participaram deste estudo, 67 por amostra aleatória simples (AAS) e 180 por 
recrutamento não-probabilístico, incluindo amostragem bola de neve, proximidade geográfica com os recrutados por AAS (que participaram por convite), bem como a participação decorrente de evento da área. No sorteio empregou-se o programa SPSS (Statistical Packet for Social Science), versão 14.0.

Como a listagem solicitada constava apenas de nomes e endereços dos profissionais, coube ao pesquisador a confirmação dos respectivos endereços, bem como de um consentimento prévio, por telefone, do profissional CD para participar do estudo.

Após estabelecer esse contato prévio com o $C D$, o pesquisador levou até o local um questionário auto-aplicável com o prazo de três dias úteis para o preenchimento do mesmo. Ao perceber que isso não estava sendo cumprido, optou-se por estabelecer concomitantemente uma segunda forma de coleta não probabilística.

\section{Coleta de dados}

Os dados foram coletados mediante questionário auto-aplicável padronizado, construído pelo autor desta pesquisa avaliado em relação ao conteúdo e objetividade por três pesquisadores da área e posteriormente testado em um grupo de 10 cirurgiões-dentistas de consultórios dentários que não faziam parte da amostra principal. O instrumento é apresentado no Apêndice I.

O questionário utilizado foi composto por cinco partes. A primeira referente a dados pessoais como sexo, cor, data de nascimento, mão dominante, prática e freqüência de atividade física e que partes do corpo eram requisitadas durante essa atividade. A segunda parte era referente à ocorrência de efeito(s) indesejável(is) que o profissional julgasse sofrer ou ter sofrido em decorrência do 
desempenho de seu trabalho no ambiente ocupacional como cirurgião-dentista. Em caso de mais de um efeito indesejável, o profissional deveria sinalizar com um asterisco $\left({ }^{*}\right)$ aquele manifestado de forma mais severa para ele, e, a partir deste, citar em qual(is) parte(s) do corpo ele era acometido por esse efeito intolerável e qual o tempo de permanência do mesmo. A terceira parte foi composta por perguntas a respeito do conhecimento do profissional sobre os termos LER e DORT, se ele fazia uso de estratégia(s) para se prevenir desses problemas de saúde, se julgava haver correlação dos sintomas prévios relatados com o que ele sabia a respeito das LER/DORT, se já tinha tido diagnóstico de LER/DORT e se já tivera episódios de afastamento em decorrência disso em sua vida profissional. A quarta parte questionava a respeito do tempo de trabalho como $C D$, carga horária, realização de pausa entre os atendimentos, procedimentos mais realizados em consultórios, qual o mais freqüente e há quanto tempo o era. A quinta parte era referente aos equipamentos utilizados em suas rotinas diárias e era finalizada com uma pergunta subjetiva em que o profissional deveria dizer se achava que o uso freqüente de alguns daqueles equipamentos motores poderia vir a desencadear alguns dos efeitos adversos citados na segunda parte do questionário.

Após o sorteio aleatório de 349 CD a partir da listagem de 1.274 solicitada pelo CRO-SP, iniciou-se o contato prévio por telefone com os profissionais para agendamento de horário para entrega do questionário. Vale ressaltar que, na maioria das vezes, esse contato era estabelecido com as secretárias dos consultórios e que essas, embora agendassem o horário de entrega, não garantiam a participação do profissional no estudo. Alegavam que, apesar da 
falta de tempo dele, iriam passar as instruções e data de recolhimento para o CD do local.

Decorridos três dias úteis, a pesquisadora principal (B.A.S.) retornava para recolher o questionário preenchido. Durante as primeiras coletas, a pesquisadora observou que os CD não cumpriam o tempo prévio determinado - três dias úteis para recolhimento e que o tempo médio de devolução do instrumento para o pesquisador era de dez dias. Foram consideradas perdas os casos de não resposta após dez dias úteis e três contatos por telefone posteriores aos dias decorridos na tentativa de recolhimento do instrumento. A coleta de dados iniciouse em junho de 2006 e terminou em 31 de outubro do mesmo ano e a opção em estender a coleta de dados para voluntários que não haviam sido sorteados iniciou-se em meados de julho seguindo os mesmos prazos e procedimentos.

Os profissionais participantes do presente estudo tiveram orientação prévia a respeito dos objetivos desta pesquisa. Antes do preenchimento do questionário, leram um termo de consentimento livre e esclarecido anexado ao mesmo e assinaram consentindo a publicação dos dados e manutenção do anonimato.

O estudo foi realizado de acordo com os princípios éticos que constam na resolução 196/1996 do Conselho Nacional de Saúde. A coleta de dados foi iniciada após o recebimento do parecer favorável fornecido pelo Comitê de Ética em Pesquisa com Seres Humanos da Escola de Enfermagem de Ribeirão Preto da Universidade de São Paulo sob o número 0129/2005.

\section{Análise de Dados}

Empregou-se uma análise de Regressão Logística binária, cujo modelo apresentou os seguintes componentes: a) variável resposta dicotômica: 
apresentar ou não algum efeito indesejável; b) preditores ou variáveis explicativas: sexo (dicotômica), idade (proporcional), prática de atividade física regular (dicotômica), tempo de atuação como cirurgião dentista (proporcional) e realização de pausa entre os atendimentos (dicotômica).

De fato, para o nível de significância $\alpha=0,05$, o modelo de entrada forçada de todos os preditores (método ENTER no SPSS) indica que apenas a variável sexo (marginalmente significante, $C R=0,573, p=0,056$ ) e pausa entre os atendimentos $(C R=0,514, p=0,022)$ apresentaram significância estatística com a presença de algum efeito indesejável. Para análise bivariada foi utilizado o Teste Qui - quadrado e Exato de Fisher conforme mostra a Tabela 10. 


\section{RESULTADOS E DISCUSSÃO}

Foram sorteados 349 cirurgiões-dentistas com registro na sede regional de Ribeirão Preto do CROSP de São Paulo. Desses, houve tentativa de estabelecer contato prévio por telefone com 161(46\%) profissionais. Entre os 161 CD contatados, 43 não foram encontrados, 31 mudaram de endereço, 10 recusaramse a participar do estudo, 7 não devolveram o instrumento após três visitas, 2 foram a óbito, um estava afastado do trabalho. Dessa forma, 67 desses participaram do estudo. O restante da amostra constituiu-se de 180 cirurgiõesdentistas que atuavam nas mesmas localidades dos sorteados ou nas proximidades, e que aceitaram participar do estudo. Sendo assim, a amostra de 247 CD compunha-se de $67(27,1 \%)$ profissionais provenientes de sorteio aleatório e 180 (72,9\%) de outros voluntários.

A amostra constituiu-se por $106(42,9 \%)$ CD do sexo masculino e 141 $(57,1 \%)$ CD do sexo feminino. A idade média entre os participantes do sexo masculino foi de 40,50 anos $( \pm 12,42)$ e do sexo feminino foi de 37,16 anos $( \pm 9,24)$. A média do tempo de atuação profissional entre os $C D$ do sexo masculino foi de 16,35 anos $( \pm 11,45)$ e do sexo feminino foi de 14,26 anos $( \pm 8,97)$.

A opção pelo procedimento de amostragem probabilística justifica-se tendo em vista a redução de viés de seleção dos participantes, que são recrutados ao acaso. No entanto, dado que quase $3 / 4$ dos recrutamentos foram voluntários, os resultados não deveriam desconsiderar os eventuais efeitos desse viés de seleção.

Apesar dos inconvenientes descritos, os dados obtidos oferecem indicações sobre as características da população estudada em relação às queixas 
osteomusculares, nervosas e vasculares questionadas, aos equipamentos motores utilizados na rotina de trabalho diário, aos procedimentos mais freqüentes relatados nos consultórios, bem como à ocorrência de LER/DORT nessa população e às possíveis correlações entre essas variáveis.

O delineamento seccional pode acarretar viés de memória. Outro tipo de viés comum a esse delineamento é o de causalidade reversa, já que as informações sobre exposição e desfecho foram coletadas ao mesmo tempo. Conseqüentemente, não se pode afirmar, definitivamente, com base nos resultados do presente estudo, que o uso de determinados equipamentos motores ou que o desempenho diário de determinados procedimentos odontológicos expõem mais ou menos os participantes a determinados efeitos indesejáveis, nem que estes são causados pelo uso freqüente de determinados equipamentos, e, ainda, que os participantes sintomáticos sofram de LER/DORT instaladas em função de sua profissão como CD; mas testes estatísticos poderão indicar se determinadas variáveis como sexo, prática de atividade física regular, tempo de atuação profissional e realização de pausa entre os atendimentos poderão ser considerados fatores de risco ou não para o aparecimento de determinados efeitos indesejáveis como alguns dos citados no presente estudo. 
Tabela 1. Distribuição dos cirurgiões-dentistas segundo características sóciodemográficas. Ribeirão Preto, São Paulo, 2006.

\begin{tabular}{|c|c|c|}
\hline Variável & Freqüência ( $N=247)$ & Percentual (\%) \\
\hline \multicolumn{3}{|l|}{ SEXO } \\
\hline $\begin{array}{l}\text { Masculino } \\
\text { Feminino }\end{array}$ & $\begin{array}{l}106 \\
141\end{array}$ & $\begin{array}{l}42,9 \\
57,1\end{array}$ \\
\hline \multicolumn{3}{|l|}{ FAIXA ETÁRIA } \\
\hline Até 29 anos & 58 & 23,5 \\
\hline 30 a 39 anos & 88 & 35,6 \\
\hline 40 a 49 anos & 58 & 23,5 \\
\hline 50 a 59 anos & 31 & 12,5 \\
\hline 60 e mais & 12 & 4,85 \\
\hline \multicolumn{3}{|l|}{ COR } \\
\hline Branco & 238 & 96,4 \\
\hline Não branco & 9 & 3,6 \\
\hline \multicolumn{3}{|l|}{ MÃO DOMINANTE } \\
\hline Direita & 226 & 91,5 \\
\hline Esquerda & 15 & 6,1 \\
\hline Ambas & 6 & 2,4 \\
\hline
\end{tabular}

A Tabela 1 mostra uma proporção similar entre os sexos com uma ligeira maioria de participantes do sexo feminino, representando $57,1 \%$ da amostra contra $42,9 \%$ composta pelo sexo oposto.

Segundo Garcia (2006), que encontrou em seu estudo com cirurgiõesdentistas uma proporção entre os sexos muito semelhante à do presente estudo, essa mesma similaridade é proporcional à real população de cirurgiões-dentistas no país.

A média de idade dos profissionais participantes do presente estudo foi de 38,65 anos, variando de 22 a 75 anos. Verifica-se na Tabela 1 que um maior número de CD atuantes encontra-se na faixa etária de 30 a 39 anos, sendo esta considerada uma faixa etária produtiva (SANTOS FILHO, 1999; OLIVEIRA, SLAVUZKY, 2001; SANTOS FILHO et al, 2001; REGIS FILHO et al, 2006). 
Embora, a literatura não traga informações a respeito de características raciais de $C D$, o presente estudo relata uma proporção de $96,4 \%$ de profissionais brancos e 3,6\% de não brancos, segundo relatos dos mesmos. Quanto à mão dominante, $226(91,5 \%)$ participantes relataram ser destros, $15(6,1 \%)$, sinistros e $6(2,4 \%)$, ambidestros. Proporção semelhante foi encontrada em estudo com CD do Nebraska e de outros países (STOCKSTILL et al, 1993).

Tabela 2. Distribuição dos cirurgiões-dentistas segundo características comportamentais (prática de atividade física regular e regiões do corpo mais recrutadas durante a prática) avaliadas de acordo com o critério: sexo. Ribeirão Preto, São Paulo, 2006.

\begin{tabular}{|c|c|c|c|c|c|}
\hline \multirow{2}{*}{ VARIÁVEL SEXO } & \multicolumn{2}{|c|}{ MASCULINO } & \multicolumn{2}{|c|}{ FEMININO } & \multirow{2}{*}{$\begin{array}{c}\text { TOTAL } \\
\mathbf{N}\end{array}$} \\
\hline & $n$ & $f$ & $n$ & $f$ & \\
\hline \multicolumn{6}{|l|}{$\begin{array}{l}\text { PRÁTICA DE ATIVIDADE FÍSICA } \\
\text { REGULAR }\end{array}$} \\
\hline $\begin{array}{r}S I M \\
N \tilde{A} O\end{array}$ & $\begin{array}{l}64 \\
42\end{array}$ & $\begin{array}{l}46,0 \\
393\end{array}$ & $\begin{array}{l}75 \\
65\end{array}$ & $\begin{array}{l}54,0 \\
607\end{array}$ & $\begin{array}{l}139 \\
107\end{array}$ \\
\hline TOTAL & 106 & 43,1 & 140 & 56,9 & 246 \\
\hline \multicolumn{6}{|l|}{$\begin{array}{l}\text { REGIÕES DO CORPO MAIS } \\
\text { RECRUTADAS DURANTE A } \\
\text { PRÁTICA }\end{array}$} \\
\hline $\begin{array}{c}{ }^{*} \text { Cabeça } \\
\text { SIM } \\
\text { NÃO }\end{array}$ & $\begin{array}{l}13 \\
50 \\
63\end{array}$ & $\begin{array}{l}39,4 \\
47,6 \\
45,7\end{array}$ & $\begin{array}{l}20 \\
55 \\
75\end{array}$ & $\begin{array}{l}60,6 \\
52,4 \\
54,3\end{array}$ & $\begin{array}{l}33 \\
105 \\
138\end{array}$ \\
\hline${ }^{*}$ Tronco & & & & & \\
\hline $\begin{array}{l}S I M \\
N \tilde{A} O\end{array}$ & $\begin{array}{l}27 \\
36\end{array}$ & $\begin{array}{l}45,0 \\
46,2\end{array}$ & $\begin{array}{l}33 \\
42\end{array}$ & $\begin{array}{l}55,0 \\
53,8\end{array}$ & $\begin{array}{l}60 \\
78\end{array}$ \\
\hline TOTAL & 63 & 45,7 & 75 & 54,3 & 138 \\
\hline $\begin{array}{lc} & * \text { Membros superiores } \\
& \text { SIM } \\
& N \tilde{O} O \\
\text { TOTAL } & \end{array}$ & $\begin{array}{l}39 \\
24 \\
63\end{array}$ & $\begin{array}{l}46,4 \\
44,4 \\
45,7\end{array}$ & $\begin{array}{l}45 \\
30 \\
75\end{array}$ & $\begin{array}{l}53,6 \\
55,6 \\
\mathbf{5 4 , 3}\end{array}$ & $\begin{array}{c}84 \\
54 \\
138\end{array}$ \\
\hline $\begin{array}{lc} & * \text { Membros inferiores } \\
& \text { SIM } \\
& \text { NÃO } \\
\text { TOTAL } \quad & \end{array}$ & $\begin{array}{l}47 \\
16 \\
63\end{array}$ & $\begin{array}{l}43,9 \\
51,6 \\
45,7\end{array}$ & $\begin{array}{l}60 \\
15 \\
75\end{array}$ & $\begin{array}{l}56,1 \\
48,4 \\
54,3\end{array}$ & $\begin{array}{c}107 \\
31 \\
138\end{array}$ \\
\hline
\end{tabular}


Dentre os 247 cirurgiões-dentistas indagados sobre a prática de atividade física regular, $246(99,6 \%)$ relataram praticar ou não alguma atividade física regular e apenas um $(0,4 \%)$, não respondeu. Dentre os praticantes, uma ligeira maioria dos praticantes era do sexo feminino, compondo um percentual de $56,9 \%$ e $43,1 \%$ eram do sexo oposto..

Entre os $138(55,9 \%)$ que responderam quais partes do corpo são mais recrutadas pela prática, houve a afirmação de que os membros inferiores e superiores são as partes do corpo mais exercitadas durante a prática de atividade física regular por esses profissionais. Um estudo realizado por Szimanska (2002) com 268 CD poloneses revela que esses profissionais realizavam exercícios recrutando prioritariamente região de tronco.

No mesmo estudo, o autor traz como resultado que 219 CD relataram praticar atividade física e 49 não praticar. Dentre os que a praticavam, $56 \%$ realizavam-na como medida profilática para as lesões musculoesqueléticas; destes, $78,1 \%$ relataram efetividade da prática, enquanto $44 \%$, não tinham esse objetivo. Nesse mesmo estudo, a maioria $(36,1 \%)$, praticava atividade física numa freqüência de duas a três vezes por semana, 29,2\% exercitavam-se esporadicamente, $26,5 \%$, uma vez por semana e apenas $8,2 \%$ exercitavam todos os dias.

No presente estudo, não foi questionado o objetivo da prática dos exercícios - se por prazer, indicação médica ou outro motivo - mas constatou-se que entre os que praticavam, 139 CD - 56,5\% apresentaram um efeito indesejável no último ano e entre os que não praticavam, 107 CD - 43,5\% também apresentavam efeito indesejável no último ano. Dessa forma, não é possível inferir se a prática de atividade física por esses profissionais tem sido um fator de 
prevenção ou predisposição para que esses apresentem efeito indesejável, como os citados nesta pesquisa.

No presente estudo, observou-se também, que a freqüência da prática de atividade física entre os CD ocorreu numa média de $3,85( \pm 1,43)$ dias para o sexo masculino e $3,42( \pm 1,35)$, para o feminino. Essa média segue a freqüência de prática eleita pela maioria dos CD estudados por Szimanska (2002), conforme estudo já relatado.

Um outro estudo realizado com profissionais do Rio Grande do Sul mostrou que após a constatação de patologias musculoesqueléticas instaladas houve aconselhamento aos profissionais odontólogos em relação a mudanças posturais adotadas, bem como a indicação de exercícios moderados após a atividade laboral. Tal medida resultou em desaparecimento de $22,5 \%$ do total de casos e amenização de $16 \%$ dos que relataram problema de ombro, $19 \%$ dos que relataram problemas em região lombar (GARCIA; BLANK, 2006).

Dessa forma, conclui-se que outras variáveis devem ser consideradas para verificar se a prática de atividade física entre $C D$ é benéfica ou não para a manutenção de sua saúde no que tange aos aspectos abordados no presente estudo (dor, redução de força de preensão palmar, limitação de amplitude de movimento, rigidez, diminuição de sensibilidade tátil, intolerância ao frio, dentre outros).

Vale ressaltar que estudos que abordam essa questão devem ser mais claros ao sugerirem o benefício da prática, especificando quais atividades são realizadas, o que são "exercícios moderados", e, em que condições esses profissionais devem realizar atividade física regular para que essa seja uma aliada para a manutenção do bem-estar físico e mental desse profissional. 
Tabela 3. Caracterização das variáveis ocupacionais dos cirurgiões-dentistas segundo o tempo de trabalho, horas diárias trabalhadas, dias trabalhados por semana e realização de pausas entre os atendimentos. Ribeirão Preto, São Paulo, 2006.

\begin{tabular}{|c|c|c|}
\hline Variável & Freqüência $(n=247)$ & Percentual $(100 \%)$ \\
\hline \multicolumn{3}{|l|}{$\begin{array}{l}\text { TEMPO DE TRABALHO } \\
\text { COMO CIRURGIÃO } \\
\text { DENTISTA }\end{array}$} \\
\hline Até 5 anos & 49 & 19,8 \\
\hline 6 a 10 anos & 53 & 21,5 \\
\hline 11 a 15 anos & 39 & 15,8 \\
\hline 16 a 20 & 39 & 15,8 \\
\hline 21 a 25 & 24 & 9,7 \\
\hline 26 a 30 & 28 & 11,3 \\
\hline 31 a 35 anos & 6 & 2,4 \\
\hline Mais de 35 anos & 9 & 3,6 \\
\hline Não responderam & 0 & 0 \\
\hline Média e desvio-padrão & $15,15( \pm 10,14)$ & \\
\hline \multicolumn{3}{|c|}{$\begin{array}{l}\text { HORAS DE TRABALHO POR } \\
\text { DIA }\end{array}$} \\
\hline$\leq 4$ & 27 & 10,9 \\
\hline $5-8$ & 113 & 45,7 \\
\hline $9-12$ & 96 & 38,9 \\
\hline$>12$ & 7 & 2,8 \\
\hline Não responderam & 4 & 1,6 \\
\hline Média e desvio-padrão & $8,37( \pm 2,42)$ & \\
\hline \multicolumn{3}{|l|}{$\begin{array}{l}\text { DIAS DE TRABALHO POR } \\
\text { SEMANA }\end{array}$} \\
\hline de 1 a 4 dias & 26 & 10,5 \\
\hline 5 dias & 147 & 59,5 \\
\hline 6 dias ou mais & 69 & 27,9 \\
\hline Não responderam & 5 & 2,0 \\
\hline Média e desvio-padrão & $5,15( \pm 0,95)$ & \\
\hline \multicolumn{3}{|c|}{$\begin{array}{l}\text { REALIZAÇÃO DE PAUSA } \\
\text { ENTRE OS ATENDIMENTOS }\end{array}$} \\
\hline Sim & 124 & 50,20 \\
\hline 0 a 5 minutos & 25 & 10,1 \\
\hline 6 a 10 minutos & 44 & 17,8 \\
\hline 11 a 15 minutos & 24 & 9,7 \\
\hline 16 a 20 minutos & 7 & 2,8 \\
\hline Mais de 20 minutos & 13 & 5,3 \\
\hline Não relataram tempo & 11 & 4,5 \\
\hline Não & 113 & 45,7 \\
\hline Não responderam & 10 & 4,1 \\
\hline Média e desvio-padrão & $15,06( \pm 17,5)$ & \\
\hline
\end{tabular}


Conforme mostra a Tabela 3, um maior número de CD atuam entre seis e dez anos na profissão. Segundo Szymanska (2002), em um estudo realizado com CD para verificar as desordens musculoesqueléticas pelos aspectos ergonômicos e profiláticos nesses profissionais, aqueles que se encontravam nessa faixa de tempo de atuação relataram sofrer com, pelo menos, duas queixas, mas eram também os que menos procuravam tratamento para essas desordens musculoesqueléticas.

Nesta pesquisa, a maior parte dos CD declarou trabalhar até oito horas por dia e até cinco dias por semana, conforme a Tabela 3 , freqüência essa também presente em outros estudos realizados com essa população (REGIS FILHO; LOPES, 1997; GARCIA; BLANK, 2006). Szymanska (2002) mostra que essa carga horária não reflete apenas a carga horária de trabalhadores nacionais, como também de CD de outros países.

Com relação à realização de pausa entre os atendimentos, a mesma tabela mostra que $50,2 \%$ dos respondentes no presente estudo a faz com um tempo de 6 a 10 minutos em $17,8 \%$ dos casos. Posteriormente, verificar-se-á que a realização de pausa entre os atendimentos apresentou valores significativos para a presença ou não de efeito indesejável de acordo com teste de regressão logística.

Num estudo realizado por Rundkrantz; Johnsson; Moritz (1991) com CD, um número significativo desses profissionais que realizam pausa entre os atendimentos não sofre com sintomas cérvico-braquiais, ao contrário daqueles que não a realizam. Fato inverso foi encontrado por Szymanska (2002), ao verificar se o número de sintomas é aumentado com o tempo de atuação 
profissional para aqueles que desempenham e não desempenham pausas entre os atendimentos.

Tabela 4. Caracterização das variáveis ocupacionais dos cirurgiões-dentistas, segundo os procedimentos mais realizados em suas rotinas de trabalho. Ribeirão Preto, São Paulo, 2006.

\begin{tabular}{|c|c|c|}
\hline Variável & Freqüência ( $n=247$ ) & Percentual (\%) \\
\hline $\begin{array}{c}\text { PROCEDIMENTOS } \\
\text { REALIZADOS COM } \\
\text { MAIOR } \\
\text { FREQÜÊNCIA } \\
\text { Dentística }\end{array}$ & 83 & 33,6 \\
\hline $\begin{array}{c}\text { Tratamento de } \\
\text { canal }\end{array}$ & 18 & 7,3 \\
\hline $\begin{array}{c}\text { Confecção de } \\
\text { provisórios }\end{array}$ & 11 & 4,5 \\
\hline Cirurgia & 7 & 2,8 \\
\hline $\begin{array}{l}\text { Raspagem de } \\
\text { tártaro }\end{array}$ & 6 & 2,4 \\
\hline Profilaxia & 1 & 0,4 \\
\hline $\begin{array}{c}\text { Ajuste de } \\
\text { moldeira para } \\
\text { modelagem de } \\
\text { prótese total }\end{array}$ & 0 & 0 \\
\hline $\begin{array}{l}\text { Não informado ou } \\
\text { não relatado }\end{array}$ & 121 & 49,0 \\
\hline
\end{tabular}

A Tabela 4 mostra que, dentre os que responderam qual o procedimento mais realizado em sua rotina diária, a maioria relatou que dentística é o mais comum. No presente estudo, optou-se por questionar a respeito dos procedimentos mais realizados, pois, segundo o estudo piloto, realizado previamente, grande parte dos avaliados relatou posteriormente serem 
especialistas em determinada área e atuarem com maior freqüência em outra. Dessa forma, decidiu-se nesta pesquisa colher dados a respeito de quais procedimentos são mais realizados na rotina diária desses profissionais, quais equipamentos são mais utilizados e por quantas horas do dia fazem uso deles, para, a partir daí, tentar estabelecer alguma correlação entre o uso de determinados equipamentos de alta e baixa rotação com sintomatologia relatada em mãos.

A literatura generaliza as características do CD pela especialidade do profissional e correlaciona efeitos indesejáveis com a área de atuação. Mesmo que esse não tenha sido o procedimento do presente estudo, há uma convergência dos resultados encontrados com dados de estudos anteriores.

Michelin e Loureiro (2000) encontraram em estudo que CD que atuam na área de traumatologia bucomaxilofacial, endodontia, periodontia, dentística restauradora, odontopediatria e prótese dentária são aqueles que apresentam maior número de casos de distúrbios. Outro estudo, realizado por Nader (2006), relata que ortodontistas, protesistas, endodontistas e periodontistas são aqueles que apresentam LER.

Em ambos os estudos, protesistas e endodontistas estão presentes e apresentam efeitos adversos. No presente estudo, Dentística, tratamento de canal (Endodontia), confecção de provisórios (Prótese) e cirurgia convergem com os resultados dos estudos de Stockstill et al. (1993), que relatam efeitos indesejáveis em protesistas, cirurgiões e endodontistas e levantam a possiblidade da exposição à vibração como um agente indutor de lesões. 
Tabela 5. Efeitos adversos osteomuscular, nervoso e vascular relatados pelos cirurgiões-dentistas ao longo do tempo de atuação profissional que persistiram por tempo determinado ou vem persistindo no último ano. Ribeirão Preto, São Paulo, 2006.

\begin{tabular}{lcc}
\hline \multicolumn{1}{c}{ EFEITO INDESEJÁVEL } & FREQÜÊNCIA & $\begin{array}{c}\text { PORCENTAGEM } \\
(\%)\end{array}$ \\
\hline Dor & 125 & 50,6 \\
Redução de FPP* & 42 & 17 \\
Limitação de ADM** & 42 & 17 \\
Parestesia/formigamento & 37 & 15 \\
Rigidez & 27 & 10,9 \\
Alteração de sensibilitade tátil & 20 & 8,1 \\
Intolerância ao frio & 9 & 3,6 \\
Outros & 26 & 10,5 \\
\hline *Força de preensão palmar & & \\
**Amplitude de movimento & &
\end{tabular}

De acordo com a Tabela 5, observa-se que a queixa ou efeito indesejável mais relatado pelos CD é a dor. Num estudo realizado por Marshall et al. (1997), para descrever a prevalência e a distribuição dos sintomas musculoesqueléticos e as desordens instaladas nesses profissionais, a dor foi o sintoma mais relatado, com $64 \%$ das queixas.

Em estudo realizado na Inglaterra, a prevalência de dor e desconforto na região lombar chegou a ser maior que na região cervical. A dor é acompanhada de rigidez muscular em região de cintura escapular e ombros, sendo comuns a parestesia ou formigamentos em membros (OHARA, 1976; LITTLEJOHN, 1994; HELFENSTEIN, 1999 apud MICHELIN; LOUREIRO, 2000).

Os demais efeitos indesejáveis apontados pelos CD avaliados, como redução de força de preensão palmar (FPP), limitação de amplitude de movimento (ADM), parestesia/formigamento, rigidez e diminuição da sensibilidade 
tátil, são comuns nesses profissionais, embora a relação de causalidade ainda seja pouco investigada.

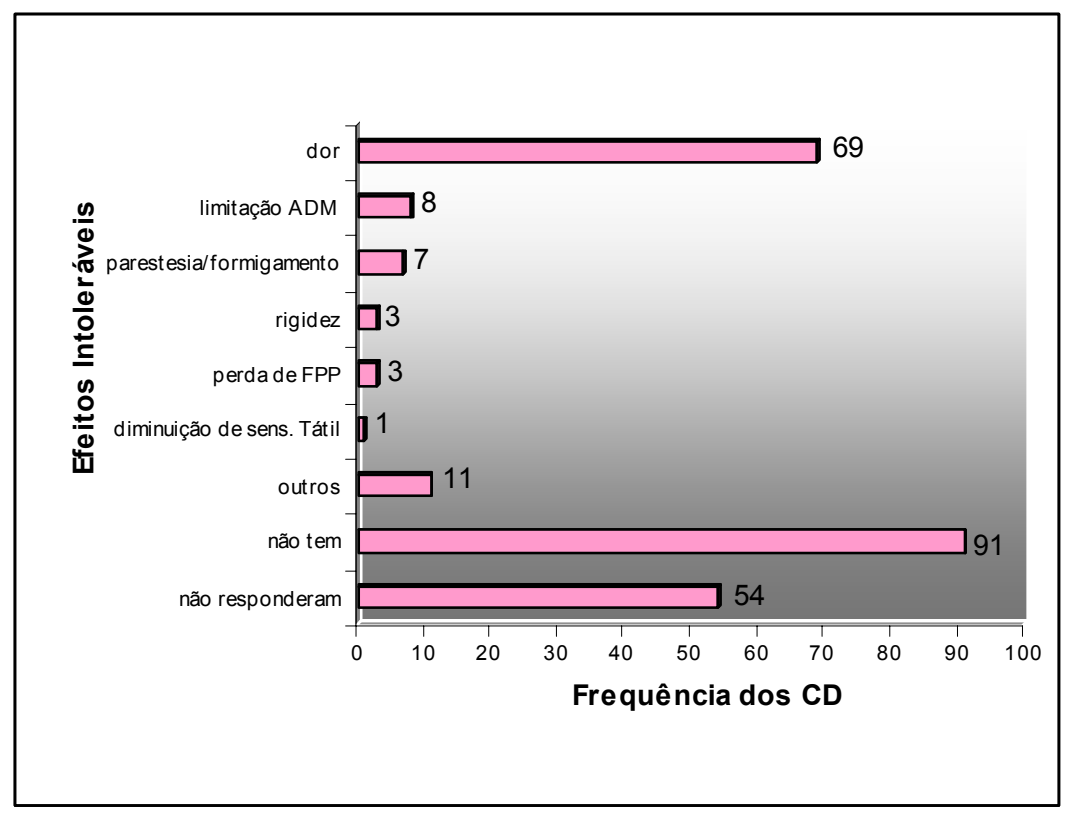

Figura 1 - Freqüências dos efeitos intoleráveis osteomusculares, nervosos e vasculares relatados por cirurgiões-dentistas de Ribeirão Preto, São Paulo, 2006.

Percebe-se neste estudo que, dentre os efeitos indesejáveis presentes na Tabela 5 e os efeitos intoleráveis mais relatados pelos CD presentes na Figura 1, existe uma convergência de determinada sintomatologia (dor, redução da força de preensão palmar, rigidez, parestesia/formigamento e a limitação da amplitude de movimento); a intolerância ao frio não foi citada como efeito intolerável por esses profissionais nesta pesquisa. 


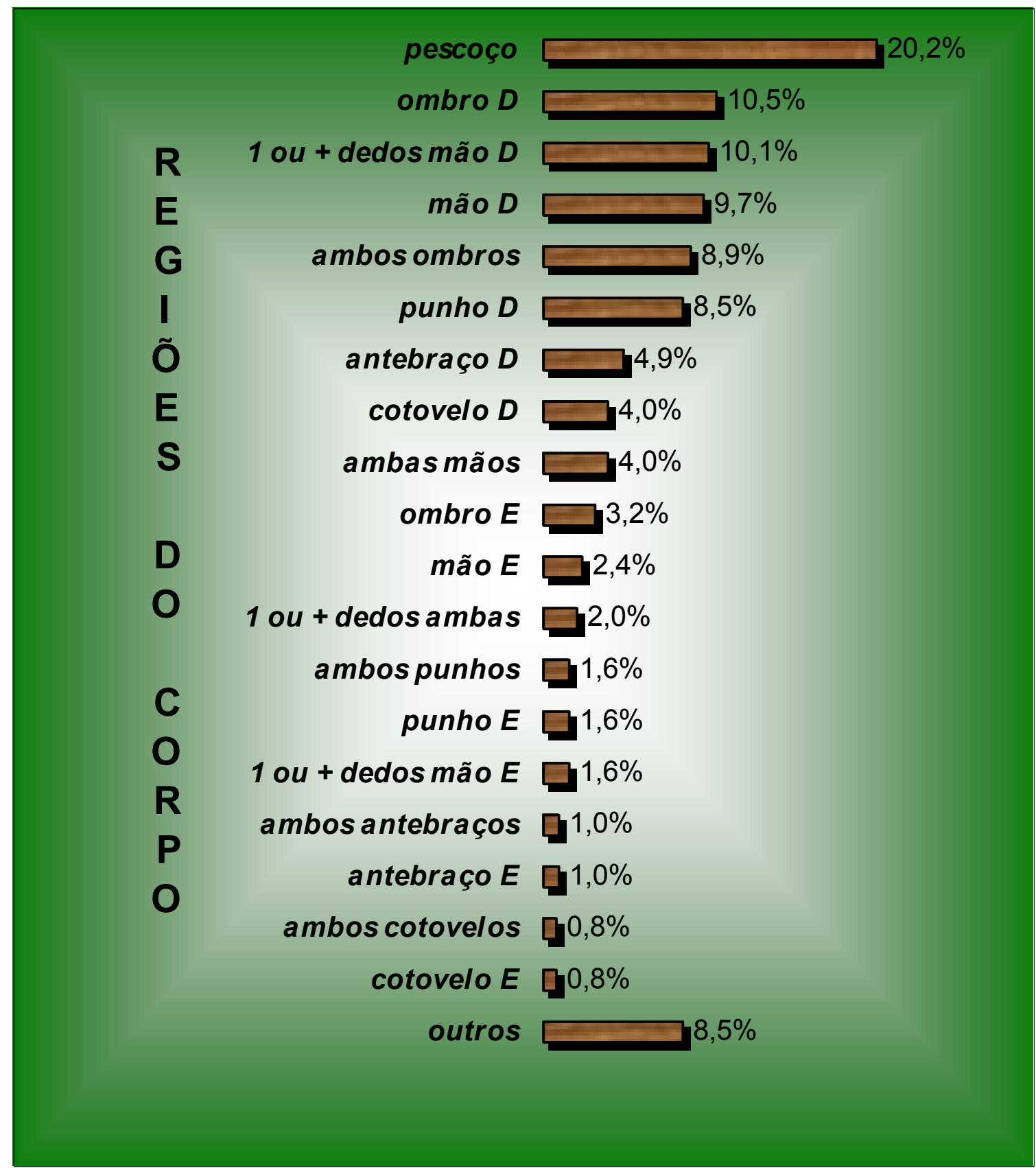

Figura 2 - Percentual das regiões do corpo mais relatadas pelos efeitos indesejáveis osteomusculares, nervosos e vasculares nos cirurgiões-dentistas segundo o Questionário Nórdico de Lesão osteomuscular (PINHEIRO et al., 2002). Ribeirão Preto, São Paulo, 2006.

De acordo com a Figura 2, percebe-se que, a partir da coluna cervical, apontada como região do pescoço pelos participantes do estudo, os efeitos intoleráveis musculoesqueléticos mais apontados foram em regiões de membro superior direito, desde ombros até extremidades. Tal fato nos traz uma 
peculiaridade comparada a estudos realizados com outros profissionais que fazem uso constante de ambos os membros superiores no desempenho do trabalho, pois, no presente estudo, essas queixas mais relatadas em um lado do corpo podem estar relacionadas não somente com as posturas físicas adotadas no desempenho da função, mas também com a manutenção da preensão dos equipamentos motores para o desenvolvimento da função.

Outro fator relevante é que, se considerarmos a quase totalidade de CD destros nesta pesquisa, as queixas relatadas por esses profissionais mais no lado direito que no esquerdo podem ter forte relação com o maior recrutamento das estruturas ósseas e musculotendíneas desse lado para o desempenho de sua função profissional. Freqüência aproximada já foi encontrada por Stockstill (1993) em estudo com 289 CD do Nebraska.

Milerad e Ekenvall (1990), em um outro estudo para averiguar os sintomas relatados em região de pescoço, ombro, braços e mãos de 99 dentistas e 100 farmacêuticos, encontrou que, com relação à dor em pescoço, ombros e braços, tais queixas são comuns nos dois grupos de profissionais, mas queixas de dor em punho, parestesia e formigamento nas mãos são mais comuns em cirurgiõesdentistas.

Os autores desse mesmo estudo concluíram que as altas freqüências desses sintomas estão relacionadas a vários fatores, dentre eles a postura de flexão e rotação cervical, a elevação dos braços e a manutenção da força de preensão palmar para a execução dos movimentos precisos e a alta demanda da visão.

Embora muito discutido até nos dias atuais a questão da sintomatologia relatada pelos cirurgiões-dentistas em função de sua prática diária de trabalho, 
poucos estudos tentaram estabelecer uma relação de causa e efeito nessa classe trabalhadora. Esta pesquisa abre caminho para futuros estudos experimentais, que poderão confirmar as prováveis correlações do uso de equipamentos motores ou instrumental que emitem vibração.

O presente estudo espera atentar os profissionais da área da saúde na questão da utilização de determinados equipamentos motores em consultórios, para a correlação de tais equipamentos e a sintomatologia relatada pelos profissionais usuários.

Vale ressaltar também que a literatura traz uma convergência nos locais do corpo acometidos por dor, parestesia ou outro efeito indesejável relatado, mas que as queixas em coluna lombar e cervical, ombros e membros superiores são comuns na maioria dos estudos consultados (STOCKSTILL et al., 1993; NAKLÁDOVÁ et al., 1995; SANTOS FILHO; BARRETO, 2001; NADER, 2006).

Alexopoulos; Stathi; Charizani (2004) relatam em seu estudo que o coeficiente de correlação com significância foi encontrado entre movimentos repetitivos de ombro e mão, excessiva imobilidade da coluna lombar e uso de equipamentos vibratórios.

Nakládalová et al. (1995), em estudo para verificar o estado de saúde de profissionais odontólogos quanto à exposição à vibração e ao excesso de uso das mãos, descrevem que $52 \%$ dos CD avaliados relataram dor na coluna, e uma freqüência expressiva de $47,5 \%$ desses relataram parestesia em dedos da mão; também foi relatado dor nas articulações da mão em $26,6 \%$ dos casos. Dentre os que relataram parestesia, exames eletromiográficos evidenciaram que 13 apresentaram comprometimento motor em nervo mediano. 
Esse mesmo autor descreve que 40 dos 57 sujeitos, que relataram parestesia, tinham-na com cervicalgia simultaneamente, e que a freqüência dessa sintomatologia aumentava tanto naqueles com exposição excessiva à vibração quanto nos outros que não eram expostos ou não faziam uso excessivo de apenas uma extremidade. Dessa forma, esse estudo sugeriu outros estudos para investigar a causa do sintoma.

Szimanska (2001) retoma o mesmo questionamento, pois sintomas relatados por CD não são prevalentes nesses trabalhadores, já que engenheiros e operários de determinadas indústrias expostos a níveis de baixa freqüência de vibração são acometidos por sintomatologia semelhante.

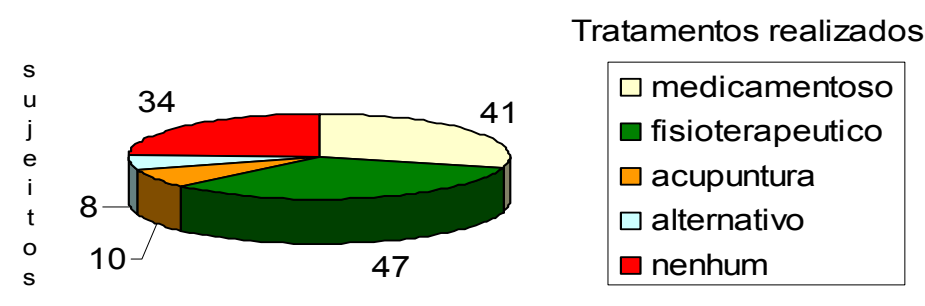

Figura 3 - Freqüência relativa dos tipos de tratamentos realizados por cirurgiõesdentistas em função do efeito intolerável relatado. Ribeirão Preto, São Paulo, 2006.

A Figura 3 traz o tratamento fisioterapêutico como o mais realizado pelos CD que relataram efeito intolerável, seguido pelo medicamentoso como os mais citados. Segundo estudo de Szymanska (2002), que descreveu aspectos ergonômicos e profiláticos em CD, essas opções de tratamento também foram as eleitas com 77,5 e $67,1 \%$ dos casos, respectivamente. 
Embora o questionamento a respeito do tratamento realizado fosse em função do efeito mais intolerável entre os indesejáveis citados, 34 (27,9\%) sujeitos, dentre os que apontaram um efeito intolerável (122 CD), não realizaram tratamento nenhum para esse incômodo.

Dentre as opções de tratamento, verifica-se no presente estudo que a eleita por 47 respondentes foi a Fisioterapia, seguida de tratamento farmacológico (medicamentoso). Essa prevalência é semelhante à encontrada em estudos com CD anteriores (STOCKSTILL et al., 1993; NADER, 2006).

Tabela 6. Resultado da Regressão logística obtido através do SPSS versão 15.0 tendo como preditores: sexo, idade, prática de atividade física regular, tempo como cirurgião dentista e realização de pausa entre os atendimentos associados com o surgimento de efeito indesejável no último ano.

\begin{tabular}{lccccccccc}
\hline \multicolumn{10}{c}{ EFEITO INDESEJÁVEL NO ÚLTIMO ANO } \\
\hline \multicolumn{1}{c}{ Variáveis } & B & S.E. & Waldf & df & $\boldsymbol{P}$ & RC & $\begin{array}{c}\text { 95,0\% C.I. } \\
\text { for Exp(B) }\end{array}$ \\
\hline & Lower & Upper & Lower & Upper & Lower & Upper & Lower & Upper \\
SEXO & $-0,558$ & 0,292 & 3,641 & 1 & 0,056 & 0,573 & 0,323 & 1,015 \\
IDADE & $-0,048$ & 0,060 & 0,648 & 1 & 0,421 & 0,953 & 0,848 & 1,071 \\
ATIV. Fís. FREQ. & 0,337 & 0,290 & 1,349 & 1 & 0,245 & 1,401 & 0,793 & 2,475 \\
TCOCD & 0,062 & 0,064 & 0,953 & 1 & 0,329 & 1,064 & 0,939 & 1,206 \\
PAUSAATEN(1) & $-0,665$ & 0,290 & 5,268 & 1 & 0,022 & 0,514 & 0,292 & 0,907 \\
CONSTANT & 1,901 & 1,360 & 1,952 & 1 & 0,162 & 6,690 & & \\
\hline
\end{tabular}


Tabela 7. Resultado da Regressão logística obtido através do SPSS versão 15.0 tendo como preditores apenas as variáveis que apresentaram significância estatística (sexo e realização de pausa entre os atendimentos) associados com o surgimento de efeito indesejável no último ano, freqüência dessas variáveis e valor de $p$, sendo $p \leq 0,05$.

\begin{tabular}{|c|c|c|c|c|c|c|c|}
\hline \multirow{2}{*}{ Variáveis } & \multicolumn{7}{|c|}{ EFEITO INDESEJÁVEL NO ÚLTIMO ANO } \\
\hline & SIM & $\%$ & NÃO & $\%$ & $\mathrm{p}$ & $\mathrm{RC}$ & TOTAL \\
\hline $\begin{array}{l}\text { masculino } \\
\text { feminino } \\
\text { TOTAL }\end{array}$ & $\begin{array}{c}58 \\
96 \\
154\end{array}$ & $\begin{array}{l}55,8 \\
69,6 \\
63,6\end{array}$ & $\begin{array}{l}46 \\
42 \\
88\end{array}$ & $\begin{array}{l}44,2 \\
30,4 \\
36,4\end{array}$ & 0,056 & 0,573 & $\begin{array}{l}104 \\
138 \\
242\end{array}$ \\
\hline $\begin{array}{l}\text { REALIZAÇÃO D } \\
\text { PAUSA }\end{array}$ & & & & & & & \\
\hline TOTAL $^{\text {nim }}$ & $\begin{array}{c}70 \\
78 \\
148\end{array}$ & $\begin{array}{l}57,4 \\
70,9 \\
63,8\end{array}$ & $\begin{array}{l}52 \\
32 \\
84\end{array}$ & $\begin{array}{l}42,6 \\
29,1 \\
36,2\end{array}$ & 0,022 & 0,514 & $\begin{array}{l}122 \\
110 \\
232\end{array}$ \\
\hline
\end{tabular}

De acordo com as Tabelas 6 e 7 observou-se que na análise multivariada, apenas a variável pausa entre atendimentos obteve diferença estatisticamente significativa $(p=0,022)$ na manifestação de efeito adverso entre os cirurgiõesdentistas. A variável sexo obteve significância marginalmente significativa $(p=$ 0,056).

Tabela 8. Resultado da regressão logística obtido através do SPSS versão 15.0 tendo como preditores: sexo, idade, prática de atividade física regular, tempo como cirurgião dentista e realização de pausa entre os atendimentos associados com o diagnóstico de LER/DORT auto-relatado.

\begin{tabular}{lccccccccc}
\hline \multicolumn{10}{c}{ DIAGNÓSTICO AUTO-RELATADO DE LER/DORT } \\
\hline \multicolumn{1}{c}{ Variáveis } & B & S.E. & Waldf & df & $\boldsymbol{p}$ & RC & \multicolumn{2}{c}{$\begin{array}{c}\mathbf{9 5 , 0} \% \text { C.I. } \\
\text { for Exp(B) }\end{array}$} \\
\hline \multirow{2}{*}{ SEXO } & Lower & Upper & Lower & Upper & Lower & Upper & Lower & Upper \\
IDADE & $-1,067$ & 0,339 & 9,909 & 1 & 0,002 & 0,344 & 0,177 & 0,669 \\
ATIV. FíS. FREQ. & 0,054 & 0,072 & 0,560 & 1 & 0,454 & 1,055 & 0,916 & 1,215 \\
T CD & 0,199 & 0,317 & 0,395 & 1 & 0,530 & 1,220 & 0,656 & 2,271 \\
PAUSA ATEN & $-0,016$ & 0,076 & 0,044 & 1 & 0,833 & 0,984 & 0,849 & 1,141 \\
CONSTANT & $-0,445$ & 0,317 & 1,972 & 1 & 0,160 & 0,641 & 0,345 & 1,192 \\
& $-1,910$ & 1,637 & 1,360 & 1 & 0,243 & 0,148 & & \\
\hline
\end{tabular}


Tabela 9. Resultado da Regressão Logística obtido através do SPSS versão 15.0 tendo sexo como o único preditor que apresentou significância estatística associado com o diagnóstico de LER/DORT auto-relatado, freqüência dessa variável e valor de $p$, sendo $p$ $\leq 0,05$.

\begin{tabular}{lccccccc}
\hline \multicolumn{1}{c}{ Variáveis } & \multicolumn{6}{c}{ DIAGNÓSTICO AUTO-RELATADO DE LER/DORT } \\
\hline \hline SEXO & $\mathrm{SIM}$ & $\%$ & NÃO & $\%$ & $\mathrm{P}$ & $\mathrm{RC}$ & TOTAL \\
Masculino & 20 & 23,3 & 66 & 76,7 & & & 86 \\
Feminino & 53 & 42,4 & 72 & 57,6 & 0,002 & 0,344 & 125 \\
TOTAL & 73 & 34,6 & 138 & 65,4 & & & 211 \\
\hline \hline
\end{tabular}

Quando indagado a respeito do diagnóstico de LER/DORT auto-relatado em CD, outra análise multivariada foi realizada com os mesmos preditores (sexo, idade, prática de atividade física regular, tempo como CD e realização de pausa entre os atendimentos) conforme mostra a Tabela 8. De acordo com a Tabela 9, a variável sexo apresentou significância estatística nessa associação e a freqüência de diagnóstico entre homens mostra-se quase o dobro quando comparadas à do sexo oposto.

O presente estudo observou que a condição de ser do sexo feminino e não realizar pausa entre os atendimentos é fator de risco para a apresentação de efeitos adversos por esses profissionais. 
Tabela 10. Correlação entre o uso de equipamentos motores de alta e baixa rotação com sintomatologia auto-relatada em mãos de CD e relação do tempo de uso desses equipamentos pelos profissionais.

\begin{tabular}{|c|c|c|c|c|c|c|c|c|c|}
\hline \multirow[t]{2}{*}{ SINTOMAS } & \multicolumn{4}{|c|}{ Alta rotação } & \multicolumn{4}{|c|}{ Baixa rotação } & \multirow[t]{2}{*}{$p$} \\
\hline & SIM & $\%$ & NÃO & $\%$ & SIM & $\%$ & NÃO & $\%$ & \\
\hline $\begin{array}{l}\text { Rigidez nos } \\
\text { dedos da mão }\end{array}$ & 10 & 15,6 & 54 & 84,4 & 6 & 30,0 & 14 & 70 & *0,194 \\
\hline $\begin{array}{l}\text { Diminuição da } \\
\text { sensibilidade tátil }\end{array}$ & 7 & 10,9 & 57 & 89,1 & 3 & 15,0 & 17 & 85,0 & *0,695 \\
\hline $\begin{array}{c}\text { Redução da força } \\
\text { de preensão } \\
\text { palmar }\end{array}$ & 19 & 29,7 & 45 & 70,3 & 5 & 25,0 & 15 & 75,0 & 0,685 \\
\hline $\begin{array}{l}\text { EQUIPAMENTOS } \\
\text { MAIS } \\
\text { UTILIZADOS NA } \\
\text { ROTINA DIÁRIA } \\
\text { DE TRABALHO }\end{array}$ & SIM & $\%$ & NÃO & $\%$ & $\begin{array}{c}\text { SEM } \\
\text { RESPOSTA }\end{array}$ & $\%$ & & $\begin{array}{l}\text { MÉ } \\
\text { TEN } \\
\text { USO }\end{array}$ & $\begin{array}{l}\text { DIA DE } \\
\text { PIÁRIO DE }\end{array}$ \\
\hline ALTA ROTAÇÃO & 234 & 94,7 & 11 & 4,5 & 2 & 0,8 & & & 4,86 \\
\hline $\begin{array}{l}\text { BAIXA ROTAÇÃO } \\
\text { COM CONTRA- } \\
\text { ÂNGULO }\end{array}$ & 203 & 82,2 & 40 & 10,2 & 4 & 1,6 & & & 3,37 \\
\hline $\begin{array}{l}\text { BAIXA ROTAÇÃO } \\
\text { COM PEÇA RETA }\end{array}$ & 155 & 62,8 & 86 & 34,8 & 6 & 2,4 & & & 2,97 \\
\hline ULTRA-SOM & 122 & 49,4 & 18 & 47,8 & 7 & 2,8 & & & 2,24 \\
\hline $\begin{array}{l}\text { VIBRADOR PARA } \\
\text { VASAGEM DE } \\
\text { GESSO }\end{array}$ & 37 & 15 & 196 & 79,4 & 14 & 5,7 & & & 0,81 \\
\hline $\begin{array}{l}\text { BAIXA ROTAÇÃO P/ } \\
\text { IMPLANTODONTIA }\end{array}$ & 15 & 6,1 & 227 & 91,9 & 5 & 2 & & & 1,87 \\
\hline POLITRIX & 13 & 5,3 & 214 & 86,6 & 20 & 8,1 & & & 0,47 \\
\hline
\end{tabular}

* Teste exato de Fisher.

Ao ser considerado o uso diário dos equipamentos motores pelos CD avaliados, observou-se que os mais utilizados na rotina diária desses profissionais foram o alta-rotação ( $94,7 \%$ dos respondentes), com média de uso de 4,86 horas diárias, em seguida, o de baixa rotação com contra-ângulo $(82,2 \%$ dos 
respondentes) com $3,37 \mathrm{~h}$, o de baixa rotação com peça reta $(62,8 \%$ dos respondentes) com $2,97 \mathrm{~h}$ e o ultra-som $(49,4 \%$ dos respondentes) com 2,24 h.

Souza (1998) realizou um estudo por meio de uma análise experimental para averiguar níveis de ruído provocados pelo alta rotação e relata que, além do trauma acústico comprovado por testes audiométricos, três outros traumas foram comprovados por Krammer (1968) - as complicações oculares, através de lesão por fragmentos de restaurações antigas ou dentes, contaminação causada pelo aerossol produzido com a associação da água, e, por último, pela inalação do óleo lubrificante utilizado na manutenção da peça, não havendo questionamento no que tange à emissão da vibração pelos equipamentos.

Posteriormente, Dylson e Darvell (1997) realizaram uma avaliação de duas turbinas de alta rotação existentes no mercado, no que diz respeito à segurança e conveniência de seu uso clínico; concluiram que ambas apresentavam inúmeros problemas, dentre eles, excessivo nível de ruído, vibração e performance insuficiente.

Michelin e Loureiro (2000), em seu estudo com CD, consideram que, quanto ao uso de equipamentos vibratórios, existe uma manifestação mais expressiva em profissionais que atuam em especialidades como traumatologia bucomaxilofacial, dentística restauradora, endodontia e periodontia, uma vez que eles se expõem à vibração pelas extremidades superiores com ou sem equipamento.

Uma enorme celeuma envolve a questão da exposição à vibração produzida por equipamentos motores em profissionais cirurgiões-dentistas, pois Mansfield (2005) relata, em sua publicação sobre as diretivas a respeito da exposição à vibração por $C D$, que dados publicados mostram que a emissão 
danosa da freqüência de vibração por equipamentos dentários é muito baixa; dessa forma, não houve interesse em estender os critérios das diretivas para o trabalho odontológico. Ao se considerar a natureza incomum da resposta humana à exposição aos equipamentos vibratórios que emitem altas freqüências, a mensuração da vibração nesses equipamentos ainda não foi necessária.

Recentemente, Regis Filho, Fadel, Pietrobon, Zmijvski e Klug (2006) analisaram a vibração produzida pelos instrumentos rotatórios de alta e baixa rotação utilizados na prática odontológica e concluíram que, em princípio, seriam necessários 17 anos e uma rotina de trabalho de 6 horas diárias para que até $10 \%$ dos cirurgiões-dentistas desenvolvessem alguma patologia associada à vibração transmitida para a mão/braço como a Síndrome do Túnel do Carpo e a da Vibração Mão/Braço.

Percebe-se que ainda não existe uma curiosidade por parte dos pesquisadores em investigar, experimentalmente, se a emissão de vibração por equipamentos, não só de alta, como de baixa rotação, é lesiva no que tange a seqüelas musculares, nervosas e vasculares, embora estudos descritivos já dêem alguma evidência a respeito desse fator, pois uma vez que esses equipamentos ainda estejam atuando em condições não usuais, seqüelas em função dos níveis de vibração inadequados podem estar sendo instaladas insidiosamente na saúde de profissionais CD.

No presente estudo, observou-se que um número considerável de $C D$ avaliados relataram fazer uso diário do equipamento de baixa rotação com contraângulo e do de baixa rotação com peça reta. Nenhum estudo ainda foi realizado para verificar as características desses equipamentos no que tange à emissão de 
vibração bem como de possíveis efeitos indesejáveis aos profissionais que apenas fazem uso desse tipo de instrumental em sua rotina de trabalho.

Dessa forma, correlacionar a sintomatologia relatada com o uso de equipamentos motores e de acordo com determinados procedimentos realizados possibilita determinadas inferências; mas como se trata de um estudo transversal e descritivo, é inviável afirmar que haja correlações entre o uso desses equipamentos e sintomatologia específica, como a citada no presente estudo.

Szymanska (2001) relata em seu estudo que não se sabe até que ponto a emissão de vibração de alta freqüência por equipamentos motores odontológicos pode causar sintomas similares àqueles da Síndrome da Vibração Mão-Braço. Todavia, Mansfield (2005) traz em seu estudo que, embora a prevalência desse tipo de desordem seja baixa entre esses profissionais, foi verificada que na Suécia é alta a incidência de lesões em mulheres que atuam na área odontológica como técnicas, higienistas e dentistas devido à exposição à vibração e existe um risco relativo dessas mulheres desenvolverem doenças em decorrência dessa exposição comparado ao daquelas que trabalham em indústrias e fazem uso de equipamentos impactantes e trituradeiras.

Segundo os avaliados, tanto para os que usam como para os que não usam equipamentos odontológicos motores com freqüência, não existe correlação com o diagnóstico de LER/DORT, pois a maioria dos que relataram fazer uso de equipamentos não teve diagnóstico de LER/DORT devido ao uso de qualquer dos equipamentos questionados. Ainda existe um desconhecimento, bem como uma descrença no que tange à questão do uso desses instrumentos por esses profissionais em agir como um fator predisponente à ocorrência de LER/DORT tanto por parte dos médicos como por parte dos próprios profissionais. 
Vale ressaltar que, segundo Helfenstein (1999), em estudo com CD, caracterizar uma relação causal entre diagnóstico de LER/DORT e atividades profissionais constitui um grande desafio, pois essa relação causal, denominada nexo causal só poderá ser afirmada mediante evidências clínicas. 


\section{CONCLUSÃO}

Foram avaliados 247 cirurgiões-dentistas no presente estudo, sendo 106 $(42,9 \%)$ do sexo masculino e $141(57,1 \%)$ do sexo feminino. Todos apresentavam registro no $\mathrm{CRO}-\mathrm{SP}$ e atuavam na cidade de Ribeirão Preto - SP. Esses profissionais apresentavam média de idade de 40,50 $( \pm 12,42)$ entre os homens e $37,16( \pm 9,24)$ entre as mulheres, variando entre 22 a 75 anos. O tempo de atuação profissional entre os participantes foi entre 0,5 a 48 anos, sendo o tempo médio de atuação de $16,35( \pm 11,45)$ anos para os homens e 14,26 $( \pm 8,97)$ anos para as mulheres.

Ao se caracterizar as atividades de trabalho do $C D$, observou-se que $(45,7 \%)$ trabalha entre cinco e oito horas por dia, sendo essa a carga horária mais citada entre os respondentes e 59,5\% atuam cinco dias por semana. Com relação à realização de pausa entre os atendimentos, $124(50,20 \%)$ dos respondentes afirmaram fazê-la sendo o intervalo mais apontado por estes, de seis a dez minutos. Dentre os demais, $113(45,75 \%)$ afirmaram não realizarem pausa e 10 $(4,05)$ não responderam.

Dentre os que relataram o tipo de procedimento mais realizado em rotina de trabalho, $83(33,60 \%)$ dos avaliados relataram dentística como procedimento mais freqüente, seguidos por tratamento de canal $(7,29 \%)$ e confecção de provisórios $(4,45 \%)$, procedimentos realizados com menor freqüência.

Em se tratando dos equipamentos mais utilizados na rotina diária, o micromotor alta rotação é o mais utilizado por $94,7 \%$ dos profissionais, seguido pelo baixa rotação com contra-ângulo $(82,2 \%)$ e o baixa rotação com peça reta, utilizado por $62,8 \%$ dos avaliados. 
Ao ser questionado a respeito de determinados efeitos adversos, o profissional poderia citar todos dentre aqueles registrados, mas era solicitado ao voluntário que sinalizasse o mais intolerável deles, o qual seria mais detalhado posteriormente. Sendo assim, o efeito mais intolerável citado foi dor, relatada por $50,6 \%$ dos respondentes, seguido em menor freqüência (17\%), por limitação de ADM (amplitude de movimento) e parestesia/formigamento (15\%).

Dentre as regiões do corpo mais acometidas pelo efeito intolerável citado, a região do pescoço, ombros e membro superior direitos foram as regiões mais citadas.

Ao se questionar o profissional a respeito das LER/DORT, (se ele sabia o que significavam as siglas), as respostas sugeriram um conhecimento a respeito da primeira (LER) e um desconhecimento em metade dos profissionais a respeito da segunda (DORT), pois dentre os 247 respondentes, $228(92,3 \%)$ sabiam o que significava LER, $15(6,1 \%)$ não sabiam e 4 (1,6\%) não responderam. Em se tratando de DORT, $118(47,8 \%)$ relataram saber o significado, 116 (47\%) não sabiam e $13(5,3)$ não responderam.

Ao ser realizado este questionamento, as perguntas vinham propositalmente em questões distintas para que não houvesse a possibilidade de o profissional responder implicando em um desconhecimento de uma das siglas na mesma resposta.

A opção em continuar respondendo às questões relativas às LER/DORT por aqueles que responderam conhecer uma das duas siglas ocorreu em função de se saber que ambos os termos são consagrados no Brasil e utilizados com o mesmo propósito; sendo assim, o respondente que relatasse conhecer um dos 
dois termos apenas, estaria apto a responder as demais, pois se tratavam do mesmo assunto.

Àqueles que relataram ter conhecimento a respeito das LER ou DORT, foram questionados se lançavam-mão de algum artifício para se prevenirem dessas; $95(38,5 \%)$ dos profissionais responderam que sim e $132(53,4 \%)$ responderam que não realizavam nada para se prevenirem das LER/DORT.

Ao serem questionados se já tiveram diagnóstico de LER/DORT em função de efeitos indesejáveis (conforme os citados no presente estudo) no período de sua vida profissional, $73(29,6 \%)$ responderam que sim e $138(55,9 \%)$ que não. Dentre os que afirmaram ter tido diagnóstico, $29(39,7 \%)$ relataram ter se afastado do trabalho de uma a cinco vezes, sendo que 68,9\% relataram um episódio apenas.

A correlação entre os CD com diagnóstico de LER/DORT e a utilização de equipamentos odontológicos não foi estabelecida, pois haveria necessidade de estudos futuros com outro delineamento para verificar se a exposição à vibração por equipamentos motores utilizados em consultórios dentários é fator predisponente para doenças ocupacionais como essas.

Embora a sintomatologia relatada por esses profissionais seja semelhante à relatada por trabalhadores que são expostos à vibração - parestesia, formigamento, perda de força de preensão palmar e de sensibilidade tátil, dentre outros - esse tipo de efeito indesejável foi relatado com uma freqüência muito inferior se comparado ao efeito dor.

Os efeitos indesejáveis acima citados foram questionados nesta pesquisa com o intuito de correlacionar esses efeitos com o uso diário de determinados equipamentos motores. Estudo realizado por Gemne (1996) lista uma série de 
distúrbios causados pelo uso de equipamentos vibratórios dentre eles dor, esbranquiçamento digital, intolerância ao frio, perda de força e de sensibilidade tátil; todavia, vale ressaltar que conhecer o equipamento, saber o tempo de uso diário, bem como a intensidade de exposição, são alguns dos fatores que devem ser estudados para se verificar aqueles predisponentes a lesões musculoesqueléticas, nervosas e vasculares.

Vale ressaltar que, embora trabalhadores expostos à vibração, dentistas ou não, relatem uma sintomatologia semelhante às citadas, a literatura afirma que existe ainda uma dificuldade em estabelecer que tais efeitos sejam causados pelos instrumentos vibratórios e que outros fatores, como peso do equipamento, design, formato anatômico, tipo de material utilizado na confecção do equipamento e marca são elementos que podem exercer influência e devem ser investigados em estudos futuros.

Outro inconveniente que vale a pena ser destacado é o grande número de profissionais que deixaram de preencher o questionário, principalmente a sessão referente a informações sobre os equipamentos odontológicos utilizados na rotina de trabalho, pois devido ao grande percentual de não resposta foi inviável tentar inferir alguma correlação entre os mesmos e os efeitos indesejáveis relatados, dentre outros inconvenientes que emergiram durante a coleta como o uso de mais de um equipamento de marcas diferentes simultaneamente.

Outros efeitos indesejáveis foram relatados no presente estudo. Embora não tenham sido descritos, os participantes mencionaram dores na coluna vertebral e membros inferiores em função da postura estática e "fechada" adotada durante os atendimentos. Para Helfenstein (1999), os quadros considerados como LER/DORT não se limitam à região cérvico-braquial. Em estudo realizado na 
Inglaterra, a prevalência de dor e desconforto como parestesia e formigamento na região lombar chegou a ser maior que na região cervical.

Dentre os participantes deste estudo, alguns profissionais deram informações extras como, por exemplo, a realização de exercícios de alongamento logo após o esforço prolongado e a realização em seus próprios consultórios de mudanças e adaptações na mobília para melhor posicionamento e facilidade para manusear equipamentos durante o atendimento.

Conforme relato de alguns profissionais participantes "As empresas que desenvolvem materiais odontológicos ainda não se preocuparam em confeccionar equipamentos mais adaptáveis a determinadas medidas antropométricas dos profissionais. Verificam-se, no entanto que, algumas medidas já foram tomadas em relação aos equipamentos motores: melhora do design, material mais leve, espessuras e tamanhos mais ergonômicos".

Diante da grande celeuma que ainda envolve a questão dos aspectos lesivos dos equipamentos motores, medidas deveriam ser iniciadas com relação à verificação desses equipamentos no que tange a sua funcionabilidade dentro dos parâmetros aceitos. A NR- 12 (Norma Regulamentadora) relativa à segurança e medicina do trabalho, dirigida e regulamentada pela Secretaria de Segurança e Saúde no Trabalho (SSST) define que os fabricantes de motosserras instaladas no país deverão introduzir nos catálogos e manuais de instrução de todos os modelos de motor os seus níveis de ruído e vibração, tempo de vida útil, dentre outras. Tal medida deveria ser estendida para equipamentos odontológicos.

A NR-17, que diz respeito aos aspectos ergonômicos no ambiente de trabalho, considera que todos os equipamentos que compõem um posto de trabalho devem estar adequados às características psicofísiológicas dos 
trabalhadores e à natureza do trabalho a ser executado; dessa forma, aspectos referentes à realização de pausas e iluminação adequada devem ser somados a outros aspectos como verificação do tempo de vida útil dos equipamentos do posto. Pois, como no Brasil a vibração ainda não é considerada um fator predisponente de risco ocupacional para os profissionais odontólogos, novas medidas de segurança deveriam ser introduzidas às políticas vigentes.

Um aspecto importante a ser considerado é um questionamento final proposto aos respondentes; se eles acreditavam que aqueles efeitos indesejáveis descritos em questão anterior tinham relação com o uso freqüente dos equipamentos motores na rotina de trabalho; Dentre os 232 respondentes, 106 $(45,7 \%)$ responderam acreditar haver correlação, $72(31,0)$ relataram não acreditar nessa relação, mas uma freqüência expressiva de 54 (23,3\%) relatou não saber.

Dessa forma, torna-se necessário, embora difícil, a tentativa de uma conscientização do profissional odontólogo com relação ao desempenho de atividades profiláticas, bem como do conhecimento a respeito dos riscos à sua saúde que predispõem o desempenho de sua profissão, seja por meio de mudanças curriculares durante a graduação ou por meio de programas preventivos.

Em estudos futuros, seria interessante investigar se a sintomatologia apresentada pelos CD que fazem uso do alta rotação é semelhante à dos que usam o baixa rotação, pois existe uma variação na freqüência de vibração emitida por esses dois tipos de micromotores, e, dessa forma, poderia surgir mais uma evidência de que o uso desses equipamentos é fator predisponente a doenças ocupacionais. 


\section{REFERÊNCIAS}

ALEXOPOULOS, E. C.; STATHI, IOANNA-CHRISTINA; CHARIZANI, F. Prevalence of musculoskeletal disorders in dentists. BMC Musculoskeletal Disorders, v. 5, p. 16, 2004.

BARREIRA, T. H. C. Abordagem Ergonômica na Prevenção da LER. Rev. Bras. Saúde Ocupacional, v. 22, n. 84, p. 51-59, out./nov./dez. 1994.

BAWA, J. Computador e saúde: manual do usuário. São Paulo: Summus, 1997.

BERNARD, B. Musculoskeletal disorders and workplace factors: a critical review of epidemiologic evidence for work-related musculeskeletal disorders of the neck, upper extremity and low back. $2^{\text {nd }}$ ed. Atlanta, Ga: Centers for Disease Control and Prevention, 1997. p. 5-28.

BRASIL. Ministério da Saúde. Protocolo de investigação, diagnóstico, tratamento e prevenção de lesões por esforços repetitivos: LER/DORT Distúrbios Osteomusculares relacionados ao Trabalho. Brasília: Ministério da Saúde, 2000.

BUSCHINELLI, J. T.; ROCHA, L. E.; RIGOTTO, R. M. Isto é trabalho de gente. Vida, doença e trabalho no Brasil. Petrópolis: Vozes, 1993. 672 p. 
CEDERLUND, R.; NORDENSKIÖLD, U.; LUNDBORG, G. Hand-arm vibration exposure influences performance of daily activities. Disabil. Rehabilitation, v. 23, n 13, p. 570-577, 2001.

COCK, N.; PIETTE, A.; MALCHAIRE, J. Can a battery of functional and sensory tests corroborate the sensorineural complaints of subjects working with vibrating tools? Int. Arch. Occup. Environ. Health., v. 73, p. 316-322, 2000.

COSTER, E. A.; CARSTENS, I. L.; HARRIS, A. M. P., Patterns of stress among dentists. J. Dental Assoc. South Africa, v. 42, p. 289-394, 1987.

COUTO, H. A. LER: doença velha com nome novo. Jornal da Odontologia, Belo Horizonte, out./nov.p. 3, 1995.

DYLSON, J. E.; DARVELL, B. W. A laboratory evaluation of two brands of disposable air turbine handpiece. Br. Dent. J., v. 182, n. 1, p. 15-21, 1997.

EGRI, D. Ler (Dort) Rev Bras Reumatol, v. 39, n. 2, p.98-106, mar./abr. 1999.

FARIA A. V. C. Riscos no trabalho de cirurgiões-dentistas: Informações e práticas referidas. 200398 f. Dissertação (Mestrado em Saúde Pública) - Escola Nacional de Saúde Pública, Fundação Oswaldo Cruz, Rio de Janeiro, 2003. 
FLENIK, M.; FUKUDA, M.; PIOTTO, M. R.; LIMA, S.; LARA, S. S.; ARAÚJO, V. L. Prevenção de cifoescoliose em estudantes de odontologia. Fisioterapia em Movimento, Curitiba, ano I, n 1, p.19-39, out./nov. 1989.

GARCIA, L. P.; BLANK, V. L. G. Prevalência de exposição ocupacionais de cirurgiões-dentistas e auxiliares de consultório dentário a material biológico. Cad. Saúde Pública, Rio de Janeiro, v. 22, n. 1, p. 97-108, jan. 2006.

GEMNE, G. Diagnostics of hand-arm system disorders in workers who use vibrating tools. Occupational and Environmental Medicine, vol. 54, n2, p. 90-95, 1997.

GOMEZ-MINAYO, C.; THEDIN-COSTA, S. M. F. A construção do campo da saúde do trabalhador: parceiros e dilemas. Cad. Saúde Pública, Rio de Janeiro, v. 13, supl. 2, p. 21-32, 1997.

GRAZIANO, K. U.; GRAZIANO, R. W.; RODRIGUES, L.; BARROS, E. R. Serviço de Odontologia. In: FERNANDES, A. T.; FERNANDES, M. O. V.; RIBEIRO FILHO, N. (Org.) Infecção hospitalar e suas interfaces na área da saúde. São Paulo: Atheneu, 2000. p.861-881.

HELFENSTEIN, M. JR. Lesões por esforços repetitivos (LER/DORT): conceitos básicos e avaliação clínica. São Paulo: Shering-Plough, 1999. 
KRAMMER, R. High speed equipment and dentists' health. Journal Prot. Dent., vol. 19, n. 1, p. 46-50, 1968.

KROEMER, K.H.E.; GRANDJEAN, E. Noise and Vibration. In: Fitting the task to the human. A text book of occupatioanal ergonomics. Londres: Taylor \& Francis, 1997. Chapter 19, p. 346-354.

LÉO, J. A. Estudo de movimentos do punho em atividades ocupacionais com diferentes níveis de automação através da eletrogoniometria. 2000. 122 f. Dissertação (Mestrado em Fisioterapia) - Centro de Ciências Biológicas e da Saúde, Universidade Federal de São Carlos, São Paulo, 2000.

LOPES, A.; VILLANACCI NETO, R. A síndrome do túnel carpal: um risco profissional para o cirurgião dentista. Revista da APCD, v. 48, n. 6, p. 1545-1552, nov./dez. 1994.

MANDEL, I. D. Occupational risks in dentistry: comforts and concerns. J. Am. Dental Assoc., v. 124, n.10, p. 41-49, 1993.

MANSFIELD, N. J. The European vibration directive: how will it affect the dental profession? Br. Dental J., v. 199, n. 9, p. 575-577, Nov. 2005.

MARSHALL, E. D.; DUNCOMBE, L. M.; ROBINSON, R. Q.; KILBREATH, S. L. Musculoskeletal symptoms in New South Wales dentists. Aust. Dent. J., v. 41, p. 240-246, 1997. 
MEDEIROS , U. V.; RIUL, L. F. Riscos ocupacionais do cirurgião dentista e sua prevenção. Rev. Paul. Odontol., v. 6, p. 34-43, 1994.

MENDES, R. Patologia do trabalho. Rio de Janeiro: Atheneu, 1995. 643 p.

MICHELIN, C. F.; LOUREIRO, C. A. Estudo epidemiológico dos distúrbios musculoesqueletais e ergonômicos em cirurgiões-dentistas. Rev. Fac. Odontol. Univ. Passo Fundo, v. 5, n. 2, p. 61-67, jul.-dez. 2000.

MILERAD, E.; EKENVALL, L. Symptoms of the neck and upper extremities in dentists. Scand. J. Work Environ. Health, v. 16, p. 129-134, 1990.

MOIMAZ, S. A. S.; SALIBA, M. A.; BLANCO, M. R. B. A força do trabalho feminino na odontologia, em Araçatuba - SP. J. Appl. Oral Sci., v.11, n. 4, p. 301-305, 2003.

MUROFUSE, N. T. Mudanças no trabalho e na vida de bancários ocasionadas por lesões por esforços repetitivos - LER. 2000. 204 f. Dissertação (Mestrado em Enfermagem Fundamental) - Escola de Enfermagem de Ribeirão Preto, Universidade de São Paulo, São Paulo, 2000.

NADER, H. A. Lesões por esforços repetitivos entre os cirurgiões-dentistas de Ribeirão Preto - SP: ocorrência e medidas de prevenção e tratamento. 2006. 83 f. Dissertação (Mestrado em Enfermagem Fundamental) - Escola de Enfermagem de Ribeirão Preto, Universidade de São Paulo, São Paulo, 2006. 
NAKLÀDALOVÁ, M.; FIALOVÁ, J.; KORYCANOVÁ, H.; NAKLÁDAL, Z. State of health in dental technicians with regard to vibration exposure and overload of upper extremities. Central Eur. J. Public Health, v. 3, p. 129-131, 1995. Suppl.

NECKING, L. E. Vibration-Induced muscle injury in the hand: experimental and clinical studies. Lund University Dissertations. Department of Hand Surgery, Malmö - University Hospital, SE- 20502 Malmö, 2003. Disponível em:

http://theses.lub.lu.se/postgrad/search.th/. Acesso em: 11 julho 2003.

NICOLETTI, S. Lesões por esforços repetitivos. Literatura técnica continuada de LER - Fasc. I. São Paulo: Bristol-Myers Squibb Brasil, 1999.

NIOSH. Occupational Exposure to Hand - Arm Vibration: Criteria for a Recommended Standard. Cincinnati, Ohio: DHHS Publication (NIOSH), 1989.

NIOSH. National Institute for Occupational Safety and Health, 1998, Musculoskeletal Disorders and Workplace Factors - A critical review of Epidemiologic evidence for work-related musculoskeletal disorders of the neck, upper extremity and low back. Publication, n. 97-141.

NOGUEIRA, D. P. Riscos ocupacionais de dentistas e sua prevenção. Rev. Bras. Saúde Ocupacional, v. 11, n. 41 p. 16-24, jan./mar. 1983. 
OLIVEIRA, J. T. Incapacidade e a "Norma Técnica sobre Distúrbios Osteomusculares Relacionados ao Trabalho - DORT". Rev. Bras. Reumatol., v. 39, n. 4, p. 217-220, jul.- ago. 1999a.

. Ler - Lesão por Esforços Repetitivos. Arq. Neuropsiquiatr., v. 57 , n. 6, p. 126-131, 1999 b.

OLIVEIRA, R. M. R. A abordagem das lesões por esforços repetitivos/distúrbios osteomoleculares relacionados ao trabalho LER/DORT no Centro de Referência em Saúde do Trabalhador do Espírito Santo - CRST/ES. 2001. 143 f. Tese (Mestrado) - Fundação Oswaldo Cruz, Escola Nacional de Saúde Pública, 2001.

OLIVEIRA, J. R.; SLAVUTZKY, S. M. B. A síndrome de Bournout nos cirurgiõesdentistas de Porto Alegre, RS. Rev. Fac. Odontol. Porto Alegre, v. 43, n. 2, p. 45-50, dez. 2001.

PECE, C. A. Z. Concepção ergonômica, desenvolvimento e otimização de um fórceps odontológico, proposta de nova sistemática exodôntica. 1998. 168 f. Dissertação (Mestrado) - Faculdade de Odontologia de São José dos Campos, Unesp, 1998.

PENNELA, I. LER: uma jornada de sofrimento no trabalho bancário. 2000. 198 f. Dissertação (Mestrado em Sociologia) - Faculdade de Filosofia, Letras e Ciências Humanas, Universidade de São Paulo, São Paulo, 2000 
PERNAMBUCO. Secretaria Estadual de Saúde. Manual de biossegurança no atendimento odontológico. Formação, v. 1, n.1, 2001.

PERRI DE CARVALHO, A. C. As Diretrizes Curriculares Nacionais dos Cursos de Graduação em Odontologia. Stomatos, v. 7, n. 12/13, p. 35-49, 2001.

PINHEIRO, F. A.; TRÓCOLI, B. T.; CARVALHO, C. V. Validação do Questionário Nórdico de sintomas Osteomusculares como medida de morbidade. Rev. Saúde Pública, v. 36, n. 3, p. 307-312, 2002.

RADWIN, R. G.; ARMSTRONG, T. J.; CHAFFIN, D. B. Power hand tool vibration effects on grip exertions. Ergonomics, v. 30, n. 5, p. 833-855, 1987.

RAMOS-GOMES, F.; ELLISON, J.; GREENSPAN, D.; BIRD, W.; LOWE, S.; GERBERDING, J. L. Accidental exposures to blood and body fluids among health cares workers in dental teaching clinics: a prospective study. J. Am. Dent. Assoc., v. 128, p. 1253-1261, 1997.

REGIS FILHO, G. I.; LOPES, M. C. Aspectos epidemiológicos e ergonômicos de lesões por esforços repetitivos em cirurgiões-dentistas. Rev. APCD, v. 51, n. 5, p. 469-474, set.-out. 1997.

REGIS FILHO, G. I.; MICHELS, G.; SELL, I. Lesões por esforços repetitivos/ distúrbios osteomusculares relacionados ao trabalho em cirurgiões-dentistas. Rev. Bras. Epidemiol, v. 9, n. 3, p.346-359, 2006. 
REGIS FILHO, G.I.; FADEL, M.A.V.; PIETROBON, L.; ZMIJVSKI, T.R.I.; KLUG,F.K. Exposição ocupacional do cirurgião dentista à vibração mecânica transmitida através das mãos - Um estudo de caso. Rev. APCD 2006; (S); 188.

REMPEL, D. M.; HARRISON, R. J.; BARNHART, S. Work-related cumulative trauma disorders of the upper extremity. JAMA, v. 267, n. 6, p. 838-842, 1992.

RUNDCRANTZ, B. L.; JOHNSSON, B.; MORITZ, U. Pain and discomfort in the musculoskeletal system among dentists. A prospective study. Swedish Dent. J., v. 15, p. $219-228,1991$.

SALIBA, T. M. Curso básico de segurança e higiene ocupacional. São Paulo: LTR, 2004. Cap. 3 Higiene Ocupacional, p. 233-270.

SANDERS, M. S.; Mc CORMICK, E. J. Environment. In: Human Factors in Engineering and Design, Nova lorque: McGraw-Hill, 1987. Chapter 17, p. 488-499.

SANTOS FILHO, S.B. Lesões por esforços repetitivos ou distúrbios relacionados ao trabalho: contexto atual e potenciais fatores envolvidos na sua gênese. In: VI ENCONTRO NACIONAL DE ESTUDOS DO TRABALHO, Belo Horizonte, MG, Abet, 1999.

SANTOS FILHO, S. B.; BARRETO, S. M. Atividade ocupacional e prevalência de dor osteomuscular em cirurgiões-dentistas de Belo Horizonte, Minas Gerais, 
Brasil: contribuição ao debate sobre os distúrbios osteomusculares relacionados ao trabalho. Cad. Saúde Pública, v. 17, n. 1, p. 181-193, jan.-fev. 2001.

SAQUY, P. C.; CRUZ FILHO, A. M.; SOUZA NETO, M. D.; PÉCORA, J. D. A Ergonomia e as doenças ocupacionais do cirurgião dentista - Parte III - Agentes químicos e biológicos. Rev. Robrac, v. 7, n. 23, p. 50-54, 1998.

SILVERSTEIN, B.; GROSSMAN, E.; NELSON, N.; KALAT, J. Upper extremity and low back musculoskeletal disorders: state and national estimates based on workers' compensation accepted claims. In: Managing Ergonomics in the 1990s: American Automobile manufacturing Association conference proceedings, June 1997, Cincinati, Ohio.

SILVERSTEIN, B.; WELP, E.; NELSON, N.; KALAT, J. Claims incidence of workrelated disorders of the upper extremities: Washington State, 1987 Through 1995. Am. J. Public Health, v. 88, n 12, p. 1827-1833, 1998.

SOUZA, H. M. M. R. Análise experimental dos níveis de ruído produzido por peça-de-mão de alta-rotação em consultório odontológico: possibilidade de humanização do posto de trabalho do cirurgião dentista. 1998. 107 f. Tese (Doutorado em Saúde Pública) - Escola Nacional de Saúde Pública, Fundação Oswaldo Cruz, Rio de Janeiro, 1998. 
STOCKSTILL, J. W.; HARN, S. D.; STRICKLAND, D.; HRUSKA, R. Prevalence of Upper Extremity Neuropathy in a Clinical Dentist Population. JADA, v. 124, n. 8, p. 67-72, August 1993.

SZYMANSKA, J. Dentist's hand symptoms and high- frequency vibration. Ann. Agric. Environ. Med., v. 8, p. 7-10, 2001.

SZYMANSKA, J. Disorders of the musculoskeletal system among dentists from the aspect of ergonomics and prophylaxis. Ann. Agric. Environ. Med., v. 9, p. 169-173, 2002.

TEIXEIRA, M. L. P.; FREITAS, R. M. V. Acidentes do trabalho rural no interior paulista. São Paulo em Perspectiva, v. 17, n. 2, p. 80-81, 2003.

WILLIAMS, R.; WESTMORLAND, M. Occupational cumulative trauma disorders of the upper extremity. Am. J. Occup. Therapy, v. 48, n. 5, p. 411-420, 1994. 
ANEXOS

Anexo A
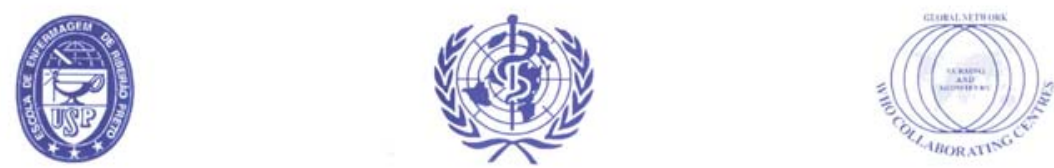

ESCOLA DE ENFERMAGEM DE RIBEIRÃO PRETO - UNIVERSIDADE DE SÃO PAULO CENTRO COLABORADOR DA ORGANIZAÇÃO MUNDIAL DA SAÚDE PARA O DESENVOLVIMENTO DA PESQUISA EM ENFERMAGEM

Avenida Bandeirantes, 3900 - Campus Universitário - Ribeirảo Preto - CEP 14040-902 - São Paulo - Brasil FAX: $55-16-633-3271 / 55-16-630-2561$ - TEI EFONES: $55-16-633-0379 / 602-3382$

COMITÊ DE ÉICA EM PESQUISA DA EERP/USP

Of.CEP-EERP/USP - 0129/2005

Ribeirão Preto, 6 de outubro de 2005

Prezada Senhora

Comunicamos que o projeto de pesquisa, abaixo especificado, foi analisado e considerado APROVADO pelo Comitê de Ética em Pesquisa da Escola de Enfermagem de Ribeirão Preło da Universidade de São Paulo, em sua $79^{\circ}$ Reunião Ordinária, realizada em 28 de setembro de 2005.

Protocolo: $\quad n^{\circ} 0576 / 2005$

Projeło: Uso de Equipamentos Vibratórios por Cirurgiōes Dentistas: Um fator de Risco para as LER / DORT.

Pesquisadores: Maria Helena Palucci Marziale (Orientadora Bárbara Aparecida Sebastião (Mestranda)

Em atendimento à Resolução 196/96, deverá ser encaminhado ao CEP - relatório final da pesquisa e a publicaçåo de seus resultados, para acompanhamento, bem como comunicada qualquer intercorrência ou a sua interrupção.

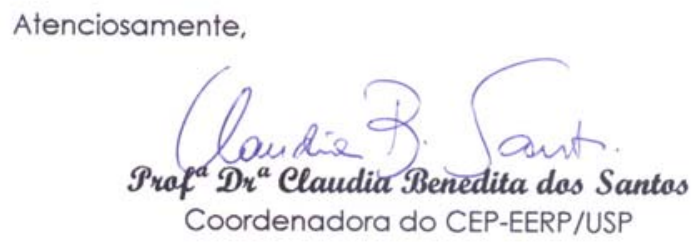

$\| m^{\circ} . S r^{\circ}$.

Profa. Dra. Maria Helena Palucci Marziale (Orientadora)

Departamento de Enfermagem Geral e Especializada

Escola de Enfermagem de Ribeirão Preto-USP 


\section{Anexo B}

\section{CONSELHO REGIONAL DE ODONTOLOGIA DE SÃO PAULO}

São Paulo, 18 de maio de 2006.

\section{Of. S. $1.811 / 2006$}

Prezada Senhora,

Em atenção ao seu e-mail, encaminhamos a relação contendo os nomes e os endereços dos cirurgiões-dentistas estabelecidos no Município de Ribeirão Preto, inscritos neste Conselho Regional de Odontologia de São Paulo.

Desejando pleno êxito na pesquisa que servirá de base para o seu projeto de mestrado, colocamo-nos à disposição e aproveitamos a oportunidade para apresentar protestos de elevado apreço e respeitosa consideração.

Atenciosamente,

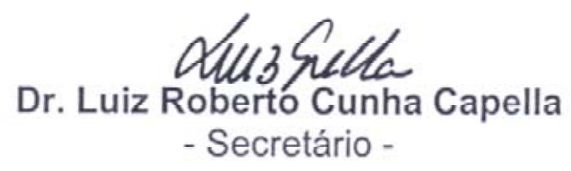

Ilma. Sra.

Bárbara Aparecida Sebastião

Departamento de Enfermagem Geral e Especializada da

Escola de Enfermagem de Ribeirão Preto - USP

e-mail: basfisio@yahoo.com.br 


\section{APÊNDICES}

\section{APÊNDICE A}

\section{QUESTIONÁRIO DE AVALIAÇÃO}

Data

Local:

\section{Dados Pessoais}

1. Código do usuário (listagem)

2. Sexo 1( ) masculino; 2( ) feminino

3. Cor: 1( ) branco; 2( ) não branco

4. Data de Nascimento

5. Mão dominante 1( ) direita; 2( ) esquerda; 3 ( ) ambas

6. Pratica atividade física regularmente? 1( ) sim; 2( ) não

Se sim, responda às questões 7 e 8 , se não, vá para a questão 9:

7. Em qual(is) parte(s) do corpo essa atividade mais requisita movimento?

1 ( ) cabeça

2 ( ) tronco

3 ( ) membros superiores

4 ( ) membros inferiores

8. Qual a freqüência dessa prática (em dias / semana)? 
II. As questões de 9 a 13 são referentes à ocorrência de alguns efeitos indesejáveis que o profissional julga sofrer ou ter sofrido em decorrência do desempenho de seu trabalho no ambiente ocupacional como cirurgião-dentista

9. Você sofre ou sofreu com algum efeito indesejável enquanto profissional (cirurgiãodentista) que vem persistindo ou persistiu no último ano?

1( ) sim; 2( ) não; 3( ) não lembra

Se sim, responda às questões de 10 a 13; se não, ou não se lembra, vá para a questão 14:

10. Certifique-se se esse(s) efeito(s) indesejável(is) está(o) relacionado(s) a algum(ns) dos descritos abaixo assinalando cada um deles com um " $\mathrm{X}$ ” e sinalize com um asterisco (*) o mais intolerável deles.

\begin{tabular}{|c|c|c|c|c|}
\hline \multicolumn{1}{|c|}{ EFEITO INDESEJÁVEL } & SIM & NÃO & $\begin{array}{c}\text { EM } \\
\text { TRATAMENTO }\end{array}$ & $\begin{array}{c}\text { SEM } \\
\text { TRATAMENTO }\end{array}$ \\
\hline 1. Rigidez nos dedos da mão & & & & \\
\hline 2. Dor & & & & \\
\hline 3. Parestesia /formigamento & & & & \\
\hline 4. Diminuição da sensibilidade tátil & & & & \\
\hline 5. Perda de força manual durante a preensão & & & & \\
\hline 6. Intolerância ao frio & & & & \\
\hline 7. Limitação de amplitude de movimento & & & & \\
\hline 8. Outros & & & & \\
\hline
\end{tabular}

11. Por quanto tempo (em meses) houve ou há a permanência desse efeito mais intolerável [daquele que você assinalou com um asterisco (*)]?

12. Em qual (quais) parte(s) do corpo relacionada(s) abaixo você foi ou está sendo acometido por esse efeito mais intolerável (aquele assinalado com um asterisco *)?

\begin{tabular}{|c|c|c|c|c|c|}
\hline PARTE DO CORPO & SIM & NÃO & PARTE DO CORPO & SIM & NÃO \\
\hline 1. pescoço & & & 11. punho D & & \\
\hline 2. ombro D & & & 12. punho E & & \\
\hline 3. ombro E & & & 13. ambos os punhos & & \\
\hline 4. ambos os ombros & & & 14. mão D & & \\
\hline 5. cotovelo D & & & 15. mão E & & \\
\hline 6. cotovelo E & & & 16. ambas as mãos & & \\
\hline 7. ambos os cotovelos & & & 17. um ou mais dedos da mão D & & \\
\hline 8. antebraço D & & & 18. um ou mais dedos da mão $\mathrm{E}$ & & \\
\hline 9. antebraço E & & & 19. em dois ou + dedos de ambas as mãos & & \\
\hline 10. ambos os antebraços & & & 20. outros & & \\
\hline
\end{tabular}


13. Que tipo de tratamento você realizou ou vem realizando para este efeito mais intolerável (aquele assinalado com um asterisco *)?

1 ( ) medicamentoso

2 ( ) fisioterapêutico (RPG, Pilates, Exercícios, Recursos eletrotermoterapeuticos, ...)

3 ( ) acupuntura

4 ( ) terapia alternativa (Reiki, cromoterapia, Florais de Bah, homeopatia, ...)

5 ( ) nenhum

III. As questões de 14 a 21 são referentes às LER/DORT

14. Você sabe o que é LER? 1( ) sim; 2( ) não

15. Você sabe o que é DORT? 1( ) sim; 2( ) não

$\underline{\text { Se você respondeu sim para uma delas (questão } 14 \text { ou 15) ou para ambas, responda às }}$ próximas questões de 16 a 21:

16. Você faz uso de algum artifício para se prevenir das LER/ DORT?

$$
\text { 1( ) sim; 2( ) não }
$$

17. Em sua opinião, os efeitos adversos relatados na questão 10 possuem alguma relação com o que você entende a respeito das LER/DORT:

1( ) sim; 2( ) não

18. Em seu caso, algum(ns) desse(s) efeito(s) relatado(s) anteriormente na questão 10 foi(ram) diagnosticado(s) clinicamente como sendo uma LER ou DORT?

1( ) sim; 2( ) não

19. Você já se afastou do trabalho por causa de LER ou DORT?

1( ) sim; 2( ) não

Se sim, responda às questões 20 e 21 , se não vá para a questão 22:

20. Quantos episódios de afastamento você já vivenciou?

21. Por quantos dias você já se afastou? (em caso de mais de um episódio, responda o de maior tempo de afastamento) 


\section{As questões de 22 a 29 são referentes a dados profissionais}

22. Qual seu tempo de atuação profissional como cirurgião-dentista (em anos)?

23. Qual sua carga horária de trabalho diária? horas

24. Quantas vezes por semana você trabalha como cirurgião-dentista?

25. Quantos meses você trabalha por ano como cirurgião-dentista?

26. Possui alguma pausa entre os atendimentos? 1( ) sim; 2( ) não

Se sim, responda à próxima questão, se não, vá para a questão 28:

27. De quanto tempo é essa pausa? (minutos)

28. Assinale com um " $\mathrm{X}$ " os procedimentos citados no quadro abaixo que você realiza em sua rotina de trabalho como cirurgião-dentista e sinalize com um asterisco $\left(^{*}\right)$ aquele realizado com maior freqüência:

\begin{tabular}{|c|c|c|}
\hline PROCEDIMENTO & SIM & NÃO \\
\hline 1. AJUSTE DE MOLDEIRA PARA MODELAGEM DE PRÓTESE TOTAL & & \\
\hline 2. $\quad$ CIRURGIA & & \\
\hline 3. CONFECÇÃO DE PROVISÓRIOS & & \\
\hline 4. DENTÍSTICA & & \\
\hline 5. PROFILAXIA & & \\
\hline 6. $\quad$ RASPAGEM DE TÁRTARO & & \\
\hline 7. TRATAMENTO DE CANAL & & \\
\hline
\end{tabular}

29. Há quanto tempo você realiza esse procedimento de maior freqüência? anos.

V. As questões inseridas no quadro abaixo são referentes ao uso de equipamentos motores por cirurgiões-dentistas. Responda aos itens que contenham o(s) equipamento(s) dos quais você faz uso freqüente

30. Responda ao(s) item(ns) do quadro que contem questões sobre alguns equipamentos odontológicos. Procure ser minucioso com relação aos dados dos equipamentos.

\begin{tabular}{|l|c|c|c|c|c|}
\hline \multirow{2}{*}{ EQUIPAMENTO } & \multicolumn{2}{c|}{ USO DIÁRIO } & \multirow{2}{*}{ MARCA } & \multirow{2}{*}{$\begin{array}{c}\text { ANO DE } \\
\text { AQUISIÇ̃̃o }\end{array}$} & $\begin{array}{c}\text { TEMPO DE USO } \\
\text { DIÁRIO } \\
\text { (HORAS) }\end{array}$ \\
\hline & SIM & NÃO & & & \\
\hline BAIXA ROTAÇÃO PARA IMPLANTODONTIA & & & & & \\
\hline BAIXA ROTAÇÃO COM PEÇA RETA & & & & & \\
\hline BAIXA ROTAÇÃO COM CONTRA-ÂNGULO & & & & & \\
\hline POLITRIX & & & & & \\
\hline ULTRA-SOM & & & & & \\
\hline VIBRADOR PARA VASAGEM DE GESSO & & & & & \\
\hline ALTA-ROTAÇÃO & & & & & \\
\hline
\end{tabular}

31. Você acredita que o uso de algum(ns) desse(s) equipamentos motores venha desencadear algum(ns) dos sintomas ou acometimentos citados na questão 10?

1( ) sim; 2 ( ) não; 3 ( ) não sei 


\section{APÊNDICE B}

\section{CARTA DE ESCLARECIMENTO}

Nome da pesquisa: Efeitos adversos na saúde de cirurgiões-dentistas e possíveis correlações com o uso de equipamentos motores

Pesquisadora responsável: Barbara Aparecida Sebastião

Endereço: Rua Ângelo Belloni, $\mathrm{n}^{\circ} 358$ / apto. 13. Parque Bandeirantes - Ribeirão Preto/SP; CEP: 14090-400. Telefone: (16) 36276388

E-mail: basfisio@yahoo.com.br

Este estudo foi desenvolvido junto ao Programa de Pós Graduação em Enfermagem Fundamental da Escola de Enfermagem de Ribeirão Preto - USP e apresentado ao Programa como Dissertação de Mestrado na linha de pesquisa Saúde do Trabalhador. Trata-se de uma investigação a respeito das possíveis correlações entre o uso de equipamentos motores por cirurgiões-dentistas e os efeitos adversos relatados por esses profissionais. Os resultados da pesquisa serão utilizados para a elaboração de programas preventivos que subsidiarão a categoria profissional de CD na minimização de sintomatologia musculoesquelética, vascular e nervosa que poderão culminar com lesões instaladas. Um exemplar da Dissertação estará disponível para consulta bem como o artigo científico oriundo do presente estudo.

Desde já, agradeço a sua valiosa contribuição.

Barbara A. Sebastião

Fisioterapeuta e Pesquisadora responsável 


\section{APÊNDICE C}

\section{TERMO DE CONSENTIMENTO LIVRE E ESCLARECIDO TERMO DE CONSENTIMENTO LIVRE E ESCLARECIDO PARA PESQUISA EM SERES HUMANOS}

Prezado(a) Sr(a):

Com o intuito de realizar uma pesquisa intitulada Efeitos adversos na saúde de cirurgiões-dentistas e suas possiveis correlações com o uso de equipamentos motores, este estudo tem por objetivo identificar nos cirurgiões-dentistas, a relação entre a ocorrência de alguns sinais e sintomas bem como de determinadas doenças já diagnosticadas em decorrência de sua atividade profissional e verificar se essas possuem alguma correlação com o uso freqüente de alguns equipamentos motores dados coletados serão destinados à elaboração de minha dissertação de mestrado a qual será apresentada ao Programa de Pós-Graduação na área de Enfermagem Fundamental do Departamento de Enfermagem Geral e Especializada da Escola de Enfermagem de Ribeirão Preto da Universidade de São Paulo - USP e posteriormente publicados.

Solicito a sua colaboração no sentido de responder ao questionário auto-aplicável o qual possui questões relativas a dados pessoais, à ocorrência de qualquer acometimento que você possa ter sofrido nos membros superiores, outras especificamente referentes às LER/DORT e a outras com relação à atividade profissional e utilização de alguns equipamentos motores odontológicos.

A pesquisadora estabelecerá contato prévio com o cirurgião-dentista por telefone, se identificará e o informará a respeito do estudo; depois irá até o local atuante do profissional e deixará o instrumento (questionário) com o mesmo ou outro responsável. Após a entrega do instrumento, a pesquisadora voltará num prazo de três dias úteis para recolher o material do entrevistado respondido.

Para maiores esclarecimentos aos profissionais envolvidos no estudo em questão, os nomes e endereços dos respectivos voluntários foram gentilmente cedidos pelo CROSP (Conselho Regional de Odontologia de São Paulo) após solicitação e justificativa ao mesmo da importância dessa pesquisa para essa classe trabalhadora.Vale ressaltar que o estudo em questão não implica em nenhum ônus para o participante, tendo este a liberdade de se recusar a participar da pesquisa ou retirar seu consentimento em qualquer fase da mesma sem nenhuma penalização.

Este documento deverá ser assinado em duas vias, sendo uma retirada pelo profissional cirurgião-dentista e a outra arquivada pela pesquisadora.

Agradeço a sua colaboração, Atenciosamente,

Barbara Aparecida Sebastião

Mestranda da Escola de Enfermagem de Ribeirão Preto

Universidade de São Paulo 
Eu, concordo em participar voluntariamente da pesquisa descrita acima desde que esta não implique em riscos ou desconforto à minha saúde física e/ou mental e que os dados obtidos sejam mantidos em sigilo quanto a minha identificação.

Ribeirão Preto, de de 200

Assinatura do cirurgião-dentista

Contato com Pesquisadora:

Barbara Aparecida Sebastião

Departamento de Enfermagem Geral e Especializada

Av. Bandeirantes, 3900 - Campus da USP

CEP: $14090-902$

Ribeirão Preto/SP

Fone/Fax: (16) 36023430 / 91811461

e-mail: basfisio@yahoo.com.br 